University of Rhode Island

DigitalCommons@URI

\title{
Trade Exposure and the Polarization of Government Spending in the American States
}

\author{
Brian S. Krueger \\ University of Rhode Island, bkrueger@uri.edu \\ Ping Xu \\ University of Rhode Island, pingxu@uri.edu
}

Follow this and additional works at: https://digitalcommons.uri.edu/psc_facpubs

\section{The University of Rhode Island Faculty have made this article openly available.}

Please let us know how Open Access to this research benefits you.

This is a pre-publication author manuscript of the final, published article.

Terms of Use

This article is made available under the terms and conditions applicable towards Open Access

Policy Articles, as set forth in our Terms of Use.

\section{Citation/Publisher Attribution}

Krueger, Brian S., and Ping Xu. "Trade Exposure and the Polarization of Government Spending in the American States." American Politics Research, vol. 43, no. 5, Sept. 2015, pp. 793-820, doi:10.1177/ $1532673 \times 15572251$.

Available at: http://dx.doi.org/10.1177/1532673X15572251 


\title{
TRADE EXPOSURE AND THE POLARIZATION OF GOVERNMENT SPENDING IN THE AMERICAN STATES
}

\author{
Abstract \\ Studies of economic globalization and government spending often view the United States \\ as an outlier case. Surprisingly, ours is the first empirical study to take advantage of the variation in \\ U.S. states' exposure to global markets, ideological orientations of the governments, and the \\ relative size of the public sector, to assess the role of trade exposure on government spending in the \\ American states. Using state-level data from the past three decades, we employ Error Correction \\ Models (ECMs) to test three competing globalization theories. We find that the effect of trade \\ exposure on government spending varies across states. Our results suggest that when conservatives \\ control state governments, high levels of trade exposure negatively relate to changes in public \\ expenditures such as welfare and infrastructure. With liberal governments in power, trade \\ exposure does not accelerate state spending growth in welfare and infrastructure, which diverges \\ from the pattern found in European social democracies.
}




\section{TRADE EXPOSURE AND THE POLARIZATION OF GOVERNMENT SPENDING IN THE AMERICAN STATES}

A large number of cross-national studies have sought to assess economic globalization’s influence on government spending, particularly welfare spending in western democracies (Cameron, 1978; Katzenstein, 1985; Garrett, 1995, 1998; Rodrik, 1998; Burgoon, 2001; Garrett \& Mitchell, 2001; Genschel, 2004). These studies often view the United States as an empirical outlier that does not fit neatly into the dominant theoretical framework that reserves a special role for social democracies (Garrett, 1998; Iversen \& Cusack, 2000; Garrett, 2001; Rudra, 2002; Korpi \& Palme, 2003). It is not fully understood how economic globalization, with global trade at its core, interacts with the special features of American political institutions to influence government spending. This lack of attention is unfortunate given the U.S.'s outsized importance in the global economy and the retrenchment of many government programs over time.

With only one case to examine, empirical researchers have not well disentangled the influence of global trade on government spending in the United States. In his classic essay, Lijphart recommends that researchers use intra-nation comparisons to overcome this type of problem, “unless the political system itself constitutes the unit of analysis” (1971, 686-689). Because the first Article of the U.S. Constitution provides the U.S. Congress, and not the states, with the power to regulate international trade, using subnational U.S. units to examine the effect of trade on spending may seem to violate Lijphart's limiting condition. Yet, national trade policy only represents one of many tools that governments can use to influence the degree of international trade. For example, states often try various tactics to retain and attract businesses engaged in international trade; these tactics include lowering overall corporate tax rates, providing targeted 
incentives, loosening environmental and workplace regulations toward manufacturing, and keeping a low minimum wage ${ }^{1}$.

Indeed, the concept of market preserving federalism stemming from economics and developed by Weingast (1995) has been directly used to understand how fiscally decentralized political units will compete to create the most hospitable environments for firms engaged in international trade. In Globalization and Fiscal Decentralization, Garrett and Rodden summarize this framework’s view of the connection between federalism and economic globalization, “fiscal decentralization forces governments to compete more fiercely for mobile capital, which creates incentives for politicians to provide good investment environments, keep taxes (and rents) low, and ultimately preserve markets” (Garrett and Rodden, 2001, 10). Considering that the U.S. ranks among the most fiscally decentralized countries in the world, under this framework, American states are expected to compete against each other for globally active firms (Garrett and Rodden, 2001, 38). ${ }^{2}$

As important, and as reviewed in later sections, the key globalization theories that connect international trade with government spending rarely consider trade policy as the core theoretical concept and instead focus on the relative degree of exposure to international trade. According to these theories, state economies with low and high degrees of exposure to international trade should express different public spending patterns. Therefore, to offer a fruitful place to explore the effect of trade on government spending in the U.S. context, states most critically must exhibit varying degrees of exposure to global trade. This key condition is well met, with the relative amount of international trade varying considerably across space and over time in the American states. ${ }^{3}$

We take advantage of this wide variation in trade exposure in the American states and test the effects of trade exposure on state government spending from 1987 to $2008 .{ }^{4}$ Following the 
cross-national literature, we also test whether state-level political institutions moderate the relationship between trade exposure and government spending. Our key empirical finding is that state government ideology moderates the relationship between trade exposure and government spending categories such as welfare and infrastructure; only in conservative state governments does trade exposure ultimately lead to cuts to government spending on these programs.

The structure of the paper is as follows. In the next section, we discuss the three competing theories in the CPE literature, globalization compensation theory, efficiency theory, and new growth theory, and specify how these theories view the relationship between trade exposure and government spending. We also note that the theoretical framework that best explains the connection between trade exposure and government spending may be dependent upon specific state contexts, namely the ideological nature of the state governments. The remaining sections introduce our data and methods, present the major findings and offer a discussion of the results.

\section{Economic Globalization and Government Spending}

The effect of economic globalization on government spending has been heatedly debated in the comparative political economy literature. Although the three leading theories (compensation theory, efficiency theory, and new growth theory) each offer a competing explanation for how globalization affects government spending, they most commonly conceptualize economic globalization as the relative degree of exposure a state has to the global economy (Garrett, 1995, 1998; Katzenstein, 1985; Swank, 2005; Rudra, 2002). The compensation school maintains that economic globalization leads to welfare state expansion due to increasing citizen demand for protection against economic anxiety exacerbated by exposure to global markets, such as unemployment and wage stagnation (Cameron, 1978; Wood, 1994; Garrett, 1995, 1998; Burgoon, 2001; Boix, 2004; Scheve \& Slaughter, 2004; Walter, 2010; Schmitt \& Starke, 2011). The 
efficiency school, sometimes called the "race-to-the-bottom” or neo-liberal convergence thesis, contends that a heavy reliance on global trade leads to shrinking government spending because large public sectors repel international investment and decrease the competitiveness of export manufacturing (Garrett and Mitchell, 2001; Rudra, 2002; Swank, 2005; Genschel, 2002; Swank \& Steinmo, 2002; see also Mosley, 2005; Genschel, 2004). These two schools offer contradictory conclusions because the former emphasizes the demand by citizens for government protection, but the latter focuses on the downward pressure on government spending exerted by corporations competing in a global marketplace. New growth theory, sometimes referred to as endogenous growth theory, shares the efficiency school's focus on government's role in creating a context in which businesses can thrive in a global economy (Aschauer, 1991). However, whereas the efficiency school focuses on the benefits of limited governments, new growth theory stresses that for businesses to succeed in a global economy they will require state-maintained infrastructure, societal stability, and human capital.

\section{The Compensation School}

Cameron's (1978) seminal work shows that there is a strong positive correlation between a state's engagement in global trade and the size of the government. He concludes that international trade exposure was the best single predictor of the increase in OECD governments' tax revenues between 1960 and 1975. This work stimulated scholars’ interest in studying the effects of economic globalization on government spending in general, and welfare spending in particular.

Many empirical studies verified the positive relationship between economic globalization and government spending (Cameron, 1978; Katzenstein, 1985; Garrett, 1995, 1998; Rodrik, 1998; Burgoon, 2001; Boix, 2004; Schmitt \& Starke, 2011). These scholars contend that economic globalization opens national economies to new competition in international markets, which despite 
some benefits to the overall economy leads to feelings of economic insecurity stemming from worries of wage stagnation and job losses. Vulnerable individuals in democracies will consequently demand that their governments provide more protection against these economic pressures. Such governmental protection against the vagaries of the global economic marketplace requires the expansion of the welfare state and thus government spending. Therefore, in the long term, there will be a positive relationship between states' exposure to economic globalization and government spending, particularly on social welfare programs. The compensation theory, variously conceived, has received a considerable amount of empirical support, with many suggesting that it ranks as the best supported explanation of the link between economic globalization and the welfare state (for a review see Mosley, 2005).

\section{The Efficiency School}

Efficiency theory, with its race-to-the-bottom mantra, is the most widely recognized framework for understanding economic globalization and government spending (Mosley, 2005; Swank, 2005). It argues that exposure to globalization puts downward pressure on taxation and government expenditures. Scholars have offered several interrelated explanations for the expected negative relationship between economic globalization and government spending. A large welfare state that offers various social safety net programs to workers could negatively affect competitiveness and productivity for business because of its "upward pressures on labor costs and the dampening effects on work incentives” (Rudra, 2002, 414). Therefore, companies are hesitant to invest or remain in states with robust safety nets. Additionally, government spending requires funding, often from either borrowing or levying higher taxes from individuals or corporations. However, borrowing results in escalating interest rates and higher costs of production, and heavy taxation increases costs and depresses work motivation, both of which represent outcomes 
unappealing to international producers and capital owners (for a review see Mosley, 2005; Garrett, 2001). Since those in public office cannot electorally afford a sluggish economy, this framework suggests that governments will cut spending in the hopes of attracting and retaining producers and capital (Garrett, 1998; Rudra, 2002). ${ }^{5}$

Under globalization, national governments compete with one another to attract international producers and capital owners in order to maintain economic growth, eventually converging at the 'neoliberal bottom' in their expenditures. This logic became conventional wisdom in many public activist circles, which in part has fuelled the popular outcry against globalization (Mosley, 2005). There were even predictions and warnings that economic globalization implied the demise of the generous European welfare states (see Garrett, 1998; Rudra, 2002). However, there has only been modest empirical evidence for spending retrenchment due to economic globalization (Garrett \& Mitchell, 2001; Genschel, 2002; Rudra, 2002; Swank \& Steinmo, 2002).

\section{New Growth Theory}

The compensation and efficiency frameworks reach contradictory conclusions about the influence of economic globalization on government spending in part because the compensation school emphasizes citizens’ demand for more government spending from the state, whereas the efficiency school emphasizes corporations seeking the lowest-cost environment from states. A third perspective, the new growth theory, also emphasizes how the government can manipulate the environment in order to help corporations succeed in a globalized market. However, new growth theory does not see low taxes, low wages, and hence minimal public expenditures, as necessarily beneficial for attracting international businesses. From this standpoint, producers not only care about low costs, but also see efficient transportation routes, updated infrastructure, social stability, 
as well as human capital as favorable conditions for business to succeed (for a review see Garrett, 1995, 1998).

Therefore, according to new growth theorists, welfare spending may be associated with depressed work incentives and high costs, but it may also be an important tool for maintaining social stability. Government spending on education and public infrastructure are important collective goods that could contribute to global market success. For example, spending on education provides corporations a skilled labor force; spending on high-quality infrastructure creates stable energy supplies and efficient transportation options (Aschauer, 1991). In this sense, new growth theory sees cross-pressures on welfare type spending. By sharp contrast, government functions, especially those in education and infrastructure are seen as critically important for the success of corporations in a global marketplace, particularly in countries with advanced capitalism. Far from being inefficient, spending in these categories contributes to corporate success. Hence, new growth theorists would argue that in the face of globalization, governments may even need to spend more in areas such as education and infrastructure.

\section{Political Context as a Moderator}

Political institutions may moderate how exposure to global trade influences government spending, making each theory's applicability dependent upon specific political contexts. According to the compensation theory and efficiency theory, citizens and corporations have different preferences for government expenditures when facing global economic competition. Governments ultimately have a choice to make about which of these competing voices should direct public policy decisions. Therefore, the role of the public in establishing governments or the ideological orientation of the government in power may determine whether citizens' or corporate preferences are adopted as a policy outcome. 
Scholars have found that economic globalization has different effects in democracies and non-democracies (Rudra, 2002; Rudra \& Haggard, 2005). Presumably because government decisions are influenced by a much larger proportion of the population in democracies compared to non-democracies, democratic governments are more likely to expand government spending when the economy is increasingly exposed to international markets (Rudra \& Haggard, 2005; Rudra, 2002). Yet, even among democracies, economic globalization's effects on welfare state outcomes are far from being uniform and often times depend upon the nature of the institutions (Garrett, 1998; Piven, 2001; Mosley, 2005). One of these institutional factors is the presence of social democratic institutions and left parties in governments (Boix, 1998; Garrett, 1998; Garrett \& Mitchell, 2001; Swank, 2005; Haupt, 2010). Since anxiety from increased trade exposure can be found disproportionately among the working class, left parties based on the organizational power of the working classes are more likely to respond to their demands for increased social protection. Yet, right-wing parties are less likely to do so given that their wealthier base tends to disproportionately benefit from highly interconnected global markets (Tufte, 1980; Garrett, 1998; Huber \& Stephens, 2001; Korpi \& Palme, 2003).

We borrow this insight from the comparative political economy literature and modify it to the American context. Even though we cannot equate most U.S. state parties to the left parties found in the global context, some state party ideologies may approach this archetype. Studies demonstrate that the states have widely varying government ideologies (Garand, 1985; Berry et al., 1998) and that U.S. government elites differ in their responsiveness to the haves and have-nots (McCarty, Poole, \& Rosenthal, 2006; Bartels, 2008). As a result, state governments might have distinct reactions to globalization depending on their ideology. We propose that the compensation thesis will be more likely to hold in the most left-leaning state governments whereas the small 
government arguments of the efficiency school should be found in the most right-leaning state governments. Put more clearly, trade exposure should lead to increased rates of government spending when liberal governments are in power but decreased rates of spending when state governments are conservative.

\section{Data and Methods}

We utilize pooled cross-sectional time-series (CSTS) data from 1987 to 2008 to assess the applicability of these diverse frameworks for the American states. Broadly considered, we estimate state government spending as a function of state trade exposure, state government ideology, the interaction of trade exposure and state government ideology, as well as a set of control variables suggested by previous literature. We present the measurements and data sources of the variables below. A more detailed description of these variables and data sources are included in Appendix 1. We have also included descriptive statistics of all variables in Appendix 2.

\section{Dependent Variables}

Government spending. We use as our dependent variables three different categories of government spending as a percentage of Gross State Product (GSP)-welfare, infrastructure, and education. These are later transformed into first-order differences when used in our Error Correction Models.

\section{Independent Variables}

Trade Exposure. Following Garrett $(1995,1998)$, we use trade as a percentage of the state economy to measure trade exposure in the American states. Indeed, Rudra notes that trade relative to GSP represents the literature’s “conventional measure” of trade exposure $(2002,425)$. Since manufacturing has been central to the debate about trade openness in the U.S. and comprises the largest trade sector, we focus our attention on manufacturing export (Bernard \& Jensen, 1995). We 
would have preferred using total trade (imports + exports) as our measure, as is commonly done at the cross-national level, but state level importation data are only available for the last few years. Even so, our investigation of import and export data for the available years demonstrates that our state-level manufacturing export measure is highly correlated with the state-level total trade measure $(\mathrm{R}=.80)$. In addition, it is highly correlated with the state-level total manufacturing trade measure $(\mathrm{R}=.79){ }^{6}$ Data on state-level manufacturing exportation data are collected from the Foreign Trade Division of the Department of Commerce in the Census.

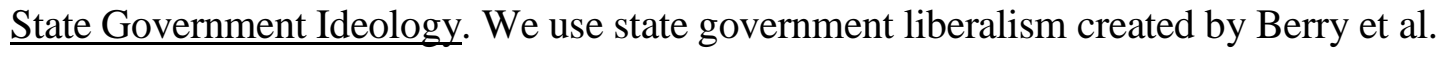
(1998) as the measure of state government ideology. This measure is based on the weighted ideological orientation of state-level legislators and the governor and ranges from 0 to 100 , with a higher value indicating a more liberal state government. Fortunately, this measure of U.S. state government ideology has been satisfactorily used to test other theories more commonly applied cross nationally. For example, Kelly and Witko (2012) have successfully used the Berry et al. (1998) measure to approximate left power when they test the applicability of a CPE theory, the Power Resource Theory, in the American context. As Kelly and Witko (2012) argue, Berry et al.'s "state government ideology measure generates a measure of left power in government that is basically consistent with previous studies in the power resources tradition and accounts for the most important complexities of applying the idea of political power resources to the context of the American states” (p418).

Recently, Shor and McCarty (2011) have developed a measure that more directly assesses state legislators' ideology, which avoids Berry et al.’s methodology of using U.S. congressional delegations as proxies. Even Berry and colleagues (2013) have acknowledged that the more direct Shor and McCarty measure is generally preferred. Yet, the Berry et al. measure has one key 
advantage, a much longer time series. Additionally, in any given year from 1996-2008, the Shor and McCarty measure only has values for between 42 and 48 states, with missing values in the other states. Apart from greater data availability, the Berry et al. measure has been shown to correlate highly with the Shor and McCarty measure and yields very similar results about the effects of government ideology on various dependent variables in replication models when compared to the more direct measure (Berry et al., 2013). Indeed, "tests of both convergent validity and construct validity demonstrate that the congressional-delegation-based measure of state government ideology remains a good alternative when research involves state-years for which the state-legislative based indicator is not available” (Berry et al., 2013, 176). Following this proposed strategy, we use the Berry et al. measure because using the Shor and McCarty measure would require us to drop nearly half of our cases. Yet, we do offer robustness checks by using the Shor and McCarty measure and present the corresponding results in the online appendix 3 and 4. These results show consistent patterns with our core findings.

Trade Exposure $\times$ State Government Ideology. Since we suggest that state government ideology may moderate the relationship between trade exposure and government spending, we also include the multiplicative term of the two core independent variables: trade exposure $\times$ state government ideology to capture the conditional effect.

\section{Control Variables}

Unemployment. Vulnerable groups such as the poor and unemployed have been shown to be supporters of government spending and protection (Lowery \& Berry, 1983; Lewis-Beck \& Rice, 1985). Therefore, we include the percentage of unemployed as a control variable.

\% Black. Gilens (1996) argues that white Americans perceive that African Americans disproportionately benefit from welfare programs, which depresses support for these programs. 
State-level studies have demonstrated a similar effect, such that states with large black minority populations have lower levels of welfare spending or less generous welfare policies (Brown, 1995; Soss, Schram, Vartanian, \& O'Brien, 2001; Fellowes \& Rowe, 2004; Hero \& Preuhs, 2007). Accordingly, we include a control for the percentage of the state population that are African Americans.

Real Per Capita Income \& Income Growth. According to Wagner (1877; see also Lowery \& Berry, 1983), economic affluence explains government spending growth, in that richer states have governments that spend more. Following Burgoon (2001) and Rudra and Haggard (2005), we include both real per capita income and real per capita income growth rate in our models. Data on state-level real per capita income are collected from the Bureau of Economic Analysis. State-level per capita income growth rate is computed by the following equation: (current year real per capita income - last year real per capita income)/last year real per capita income.

Total Roads \& License Taxes. Considerations of the nexus of economic development and public spending on infrastructure tend to focus on roads and highways (i.e. Aschauer, 1991). Because states with more road miles will have a greater need for spending to maintain state infrastructure, we include the total length of public roads within the state. We draw this information from the US Department of Transportation Federal Highway Administration. Whereas total roads measures the demand for infrastructure spending, the relative degree of a state license tax is included as a supply side measure. State license tax revenue is often targeted, at least in part, for infrastructure spending and is not easily diverted to other state needs. This measure is drawn from State and Local Government Finance of the US Census.

\% Under 18 Population. Public spending is sensitive to the age of the state population (Lynch, 2006). Because education spending is geared towards younger citizens, we include a 
measure of the youth population (\% under 18 years) drawn from the U.S. Census (Busemeyer, 2007).

Female Labor Force Participation. Because the degree of female participation in the work force has been shown to be an important predictor of public spending in several domains (Huber \& Stephens, 2001), we include the percentage of female adults in the labor force.

\section{Methods}

The panel unit root analyses show that all three dependent variables—welfare spending, infrastructure spending, and education spending — are non-stationary and the Westerlund tests detected cointegration in our panel data (Dickey \& Fuller, 1979; Phillips \& Perron, 1988; Westerlund, 2007; Persyn \& Westerlund, 2008). Well-known work by economists Bannerjee, Dolado, Galbraith and Hendry (1993) demonstrates the Error Correction Model (ECM) as an appropriate estimation for non-stationary and cointegrated time series data, and more recently researchers have successfully used ECM for TSCS data (Ehrlich, 2007; Gans-Morse \& Nichter, 2008; Schuster, Schmitt, \& Traub, 2013) . ${ }^{7}$ Given the structure of our data we use the dynamic model specification ECM to estimate the first-order change in government spending as a function of lagged government spending, a lagged term and a first-order difference term of all the independent variables and control variables (De Boef, 2001; De Boef \& Keele, 2008). The ECM specification can help minimize the potential of spuriousness with the presence of non-stationary data (De Boef \& Granato, 1997). Considering that the panel data set is unbalanced due to data availability issues with certain variables, we adopt the pairwise option in order to include all possible observations. In addition, we apply panel-corrected standard errors (PCSEs) to correct for panel heteroskedasticity and contemporaneous correlation (Beck \& Katz 1995,1996). See the online appendix for a detailed accounting of our modeling decisions, including various diagnostics. 


\section{Findings}

Table 1 presents the results for the pooled cross-sectional and time-series (CSTS) models. In Model (1)-(3), we use welfare spending, infrastructure spending, and spending on education as our dependent variables in each model. In the ECM specification, each of these dependent variables is the first-order difference of state government spending as a percentage of the GSP.

[Table 1 about here]

\section{Welfare spending}

Turning to the results ${ }^{8}$ in Model (1), the long-term effect of trade exposure, according to De Boef and Keele (2008) is defined by the coefficients of lagged trade exposure $(b=-0.016)$ and lagged welfare spending ( $\mathrm{b}=-0.037)$. The interaction term of lagged trade exposure and lagged state government ideology $(b=0.0002)$ makes straightforward interpretation of the coefficients challenging from the tables alone. Therefore, we graph a figure by using the Clarify addition to Stata 12.0 to intuitively display the long-term effect of trade exposure on welfare spending as moderated by state government ideology (King, Tomz, \& Wittenberg, 2000). ${ }^{9}$ Figure 1 displays the predicted effects of trade exposure on change in welfare spending under liberal and conservative state government when all other explanatory variables are held at their means.

[Figure 1 about here]

Figure 1 shows that in states with conservative governments, the "race to the bottom" effect is found. Under conservative state governments, lower levels of trade exposure are associated with small increases in welfare expenditures, or in other words conservative state governments only expand welfare expenditures when the state economy is relatively closed to the global economy. As trade becomes more relevant to the state economy, conservative state governments begin to cut welfare, which is consistent with the efficiency school's view that when faced with global trade 
competition, governments will make these cuts in the hopes of attracting international producers and capital. Our results suggest that the more state economies are integrated into the global economy, the deeper conservative governments will cut welfare expenditures. When a conservative state is extremely reliant on exports, the predicted change in welfare spending is nearly $-0.2 \%$ of gross state product (GSP). To put this in context, the average state spends about $2.4 \%$ of its GSP on these types of programs. Therefore, the results suggest that in the long run, substantial increases in trade exposure leads to a "race to the bottom" effect in welfare spending in states run by conservative governments.

The effect of trade exposure on welfare spending is quite different under liberal state governments. The predicted value of change in welfare expenditure is positive and this positive growth rate remains at the same level when trade exposure increases. In other words, liberal state governments increase welfare spending at the same rate ( $0.13 \%$ of GSP per year) regardless of the exposure to the global economy. This suggests that even the most liberal state governments do not conform to the compensation thesis that expects governments to make extra efforts to increase welfare spending in the face of intense global trade competition. Of course, in these liberal states, increased trade exposure also does not seem to induce a "race to the bottom" effect on welfare spending as found in conservative states.

We can conclude that trade exposure has a different effect on welfare expenditure in liberal states compared to conservative states. When exposed to global trade pressures, conservative state governments, consistent with the efficiency thesis, cut welfare expenditures, but liberal states are neither pressured to cut welfare programs nor do they make additional efforts to accelerate spending increases in this area as the compensation school predicts. 


\section{Infrastructure spending}

Model (2) uses a different dependent variable, change in infrastructure expenditure as a

percentage of GSP. ${ }^{10}$ Lagged trade exposure in addition to lagged state government ideology and the interaction term between these two variables all have significant effects on the dependent variable. Again, by using Clarify coupled with Stata 12.0 we draw Figure 2 to graphically demonstrate the interactive effects of trade exposure and state government ideology on infrastructure spending (King, Tomz, \& Wittenberg, 2000).

[Figure 2 about here]

Figure 2 shows that trade exposure has different effects on changes in infrastructure spending in liberal and conservative state governments. In states with conservative state governments, trade exposure again has a "race to the bottom" effect on infrastructure spending. Whereas low levels of trade exposure are associated with modest increases in infrastructure expenditures, conservative state governments begin to cut infrastructure expenditure once trade becomes important to the state economy. Beyond this point, with conservative governments, higher trade exposure leads to even deeper cuts in infrastructure spending. When a conservative state is very highly exposed to the global economy, the predicted change in infrastructure spending is about -.15\% of GSP. Again, for conservative governments, the evidence supports the logic of the efficiency school and does not follow new growth theory’s expectations that with increased pressures of the global market, governments will seek to maintain and attract capital by increasing expenditures on infrastructure.

For states with liberal governments, we again find that trade exposure does not have a "race to the bottom” effect on infrastructure spending but neither does it lead to additional efforts by the state governments to invest in infrastructure as new growth theory implies. In these liberal states, 
the estimates for change in infrastructure spending as a percentage of GSP do not significantly differ at the highest and lowest levels of trade exposure.

\section{Education spending}

Model (3) estimates the effect of trade exposure on changes in education spending as a percentage of the GSP. Trade exposure does not seem to have a significant long-term effect. In addition, the coefficient of the interaction term between lagged state government ideology and lagged trade exposure is not statistically significant. Unlike the previous two models, state government ideology fails to moderate trade exposure’s effect on changes in education spending. Trade exposure does have a positive short-run effect on education spending. This result suggests that when responding to the pressures of global trade, both liberal and conservative state governments reject the logic of the efficiency school in the area of education and show at least short-term behavior consistent with the societal investment approach of new growth theory.

\section{Discussion}

A large number of studies have examined how trade exposure influences government spending across countries. Scholars as diverse as Garrett and Rodden (2001), Weingast and colleagues (1995), and Piven (2001) all suggest that subnational political units within fiscally decentralized countries are particularly susceptible to the forces of economic globalization, with the U.S. ranking among the most fiscally decentralized countries in the world (Garrett\& Rodden, 2001, 38). Yet, surprisingly, no large empirical study has examined how trade exposure influences U.S. state government spending. In this piece, we offer an empirical examination of the effects of trade exposure on government spending in the context of the American states. A sub-national analysis isolating the U.S. is particularly valuable considering that the U.S. is often an empirical cross-national globalization outlier and has not always fit well into globalization theories that 
frequently center on the presence of European social democracies. ${ }^{11}$ This study offers the chance to assess how well theories of globalization developed for other contexts explain the U.S. patterns and how the special features of American political institutions influences the applicability of these theories.

We employ Cross Section Time Series (CSTS) data across 49 states from 1987-2008 to assess the long-term effect of trade exposure on government spending categories. The results show that trade exposure is often moderated by state government ideology. Facing global competition for trade, liberal and conservative state governments have quite different strategies in adjusting state government spending. Liberal state governments, with high exposure to global trade, do not make extra efforts to increase spending for education, infrastructure or welfare over the long term. In contrast, conservative state governments react to higher trade exposure by first slowing down the growth of and then cutting welfare and infrastructure expenditures (but not education).

What are the implications of these results for the theories of globalization? The welfare spending findings most support the efficiency school in that trade exposure constrains welfare spending under conservative state governments. Interestingly, our results provide no evidence in support of compensation theory. Trade exposure does not lead to the acceleration of welfare spending growth, even when the most liberal governments are in power at the U.S. state level. To be clear, regardless of the level of trade exposure, liberal governments make a similar commitment to moderately increase welfare spending.

These results are notable in that compensation hypotheses routinely receive the most empirical support when OECD countries are studied cross nationally. In fact, Mosley (2005) suggests that the very persistence of the efficiency theory's race to the bottom (RTB) logic is a puzzle needing explanation, “despite the accumulation of empirical evidence against RTB logic, 
this argument continues to characterize popular debates. What explains this apparent disconnect between social scientific research on the subject and the claims of politicians and pundits?”(359). Mosley argues that this logic persists because (1) it remains a useful ideological device for those wanting a greater reliance on free markets and (2) anecdotal stories of the social safety net being slashed to support the unfeeling needs of economic globalization makes for striking journalism. Our results offer a third explanation, in the U.S., with a high concentration of the most influential pundits and scholars, the efficiency theory’s logic seems to explain how trade exposure influenced welfare spending in conservative U.S. states over the past few decades. Many observers, at least those familiar with conservative states, are simply reacting to decades of experience that conforms to the race to the bottom logic. The logic of the efficiency school may be seldom found in European welfare states, but it is alive and well in many U.S. states. This finding echoes the comparative political economy literature that treats the United States as one of the most liberal welfare states among industrial countries.

Our finding that trade exposure's effect on spending depends on the ideological orientation of state governments is somewhat consistent with Garrett's $(1995,1998)$ argument that ideological institutions moderate the relationship between economic globalization and welfare state spending. At the cross-national level, economic globalization tends to accelerate spending on welfare state programs when social democratic parties are in power, whereas economic globalization tends to have a null or modestly negative effect under more market oriented right-wing led governments (e.g. Swank, 2005). In the context of the U.S. states, trade exposure with conservative governments tends to accelerate cuts, whereas trade exposure coupled with even the most left leaning state governments does not alter spending patterns on welfare. The moderating effect is similar to crossnational patterns but the center of gravity shifts in the U.S. states towards lower spending. This 
finding offers insights into the nature of ideology in U.S. state governments. Even though liberal governments do not cut back welfare programs in the face of high exposure to global trade, they do not act like the social democratic parties of other OECD countries by increasing the rate of spending on social safety nets. In the U.S., even the most liberal states do not have a powerful left party like the Social Democratic parties found in the comparative context, nor do they have strong politically integrated labor unions (especially in private sectors). The lack of such robust and organized left political power in the U.S. may help explain this nonconforming U.S. pattern.

New growth theory does not receive much support in the infrastructure model but receives moderate support in the education model. Indeed, trade exposure even decreases spending on infrastructure when state governments are conservative, which suggests that at least for conservative states, global competitiveness is most defined by the logic of efficiency and this logic is powerful enough to overcome arguments about the benefits of infrastructure investments. The only exception might be education spending; even under conservative state governments, trade exposure does not rollback spending in this area of human capital. Given that trade exposure leads conservative governments to cut spending in welfare and infrastructure, this null long-term ${ }^{12}$ result may be seen as a partial vindication of new growth theory. In other words, the lack of cuts to education in the face of global competition when conservatives hold power may be seen as a relative commitment to maintaining a highly skilled workforce.

Our results also suggest that increased trade exposure may be part of the story about the increased polarization in the U.S., particularly at the state level (for a review see Hetherington, 2009; Garand, 2010; McCarty, Poole and Rosenthal, 2006). To date, the bulk of attention to polarization has focused on mass and elite ideology; our results show that elite ideology differences only sometimes translates into different policy outcomes, which suggest that political 
scientists should pay more attention to policy polarization. For example, with low reliance on trade, a condition more common in the past, conservative and liberal governments grew social welfare and infrastructure programs at nearly the same rate (see Figures $1 \& 2$ ). Yet, we find that liberal and conservative government spending patterns diverge dramatically when state economies are highly exposed to international markets. Conservative governments tend to cut social welfare programs only when in a high trade environment; liberal states maintain their policy of modest increased investments regardless of trade levels. Though more work needs to be done in this area before any firm conclusions can be drawn, our results suggest that economic globalization might be an important element in growing state-level policy polarization in the U.S.

Why are conservative governments especially successful at translating their ideological policy preferences into policy outcomes under high levels of trade exposure? One possibility is that conservative governments, already inclined to cut spending on certain programs, are better able to market their policy to various policy stakeholders under pressures of globalization. This notion that proposals to cut U.S. social welfare spending would be especially salable in a highly globalized environment, particularly at the U.S. state level, has been previously advanced by Piven (2001, 34), "laissez-faire themes gained new credibility because they were tied to globalization. Markets were now international markets, and government had to get out of the way because it had no power over international markets.” In this way, we expect to see policy divergence most pronounced in states with conservative governments and high exposure to global trade.

This paper should be seen as an initial empirical study to understand the connection between economic globalization and various types of U.S. state-level spending. More work is needed. Primarily due to data limitations, our models rely on a measure of manufacturing export as a percentage of GSP to capture states' exposure to the global marketplace. Future studies 
should explore other elements of economic globalization such as foreign direct investment and importation as well as state-to-state trade. Similarly, the use of different estimation techniques and the inclusion of a wider range of control variables such as culture and other state specific factors would help establish more confidence in these results. Our range of dependent variables also could be expanded to include other spending categories, tax structures, as well as environmental regulations.

The U.S. states are rich environments to explore these issues, but to date researchers have largely ignored economic globalization as an explanation for understanding public policy in the states. This lack of attention makes sense in that the United States, and by extension most states, had been well insulated from the global marketplace in the post-war period relative to most other countries (Garrett, 2001). But over the past few decades the U.S. has become more reliant on trade, with trade levels now more similar to other OECD countries. More than anything else, our work should encourage state politics researchers to begin assessing if and how economic globalization affects state policy. 
Figure 1. Predicted value of change in welfare spending as trade exposure varies from minimum to maximum values under liberal and conservative state governments

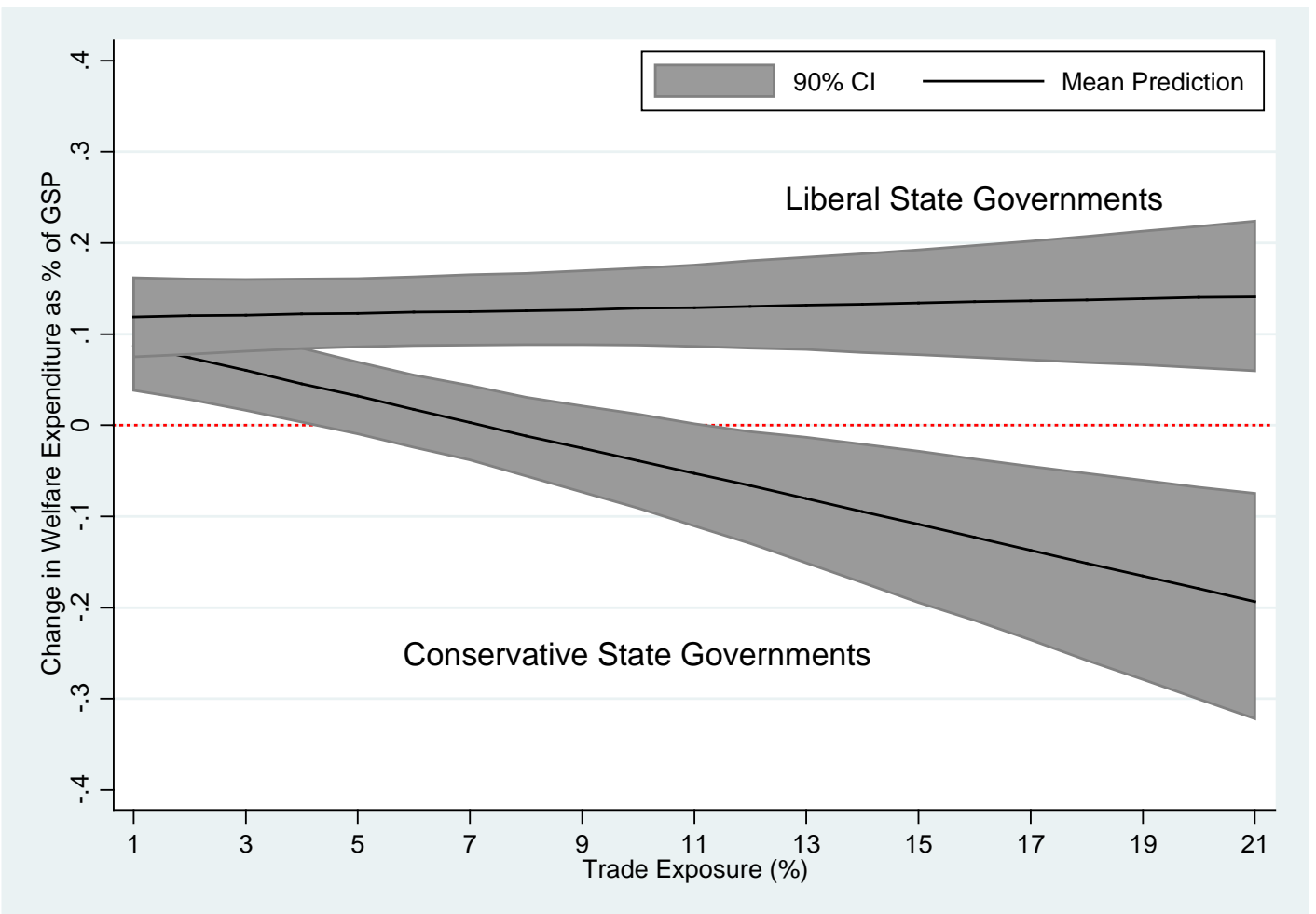


Figure 2. Predicted value of change in infrastructure spending as trade exposure varies from minimum to maximum values under liberal and conservative state governments

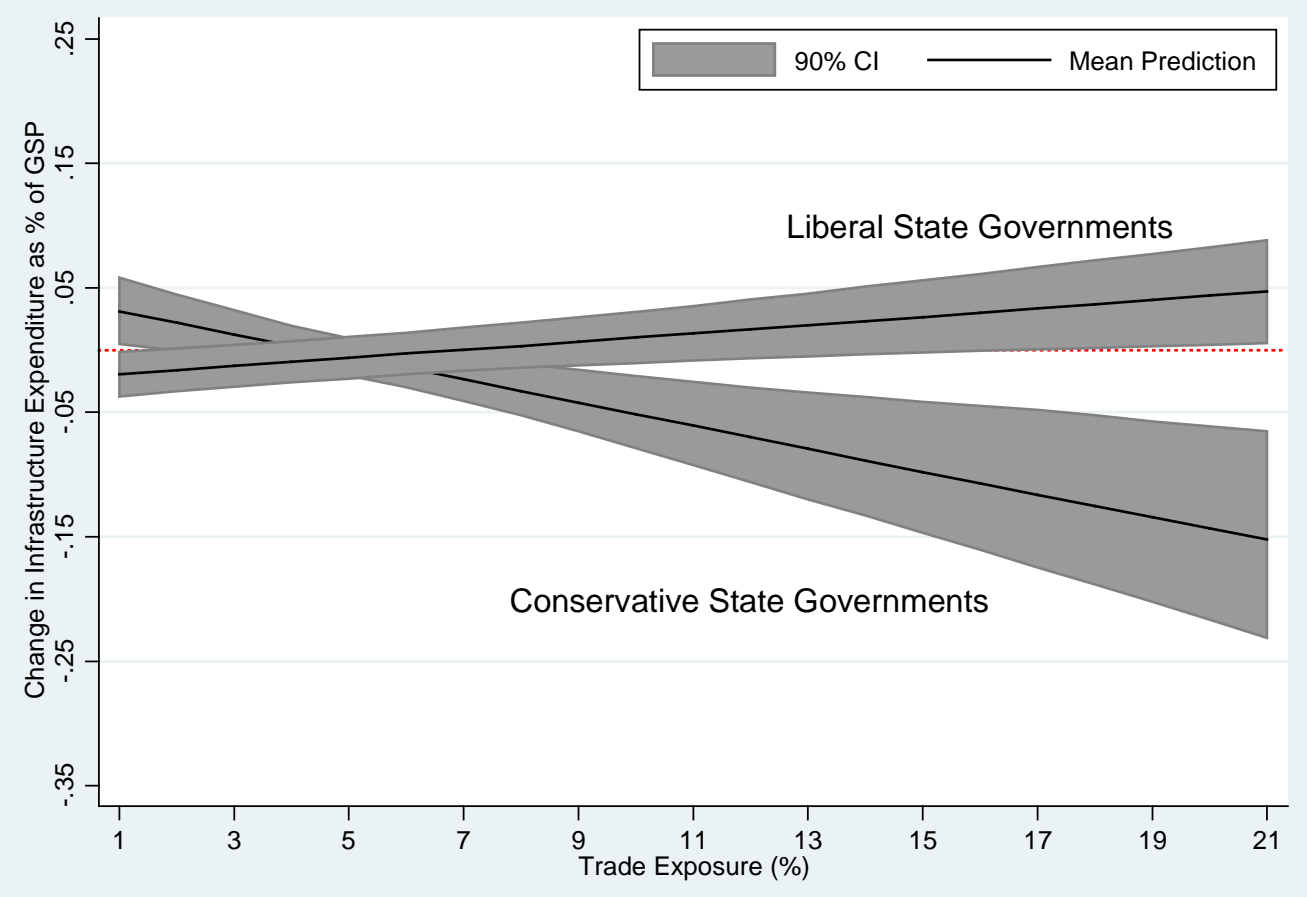


Table 1. Trade Exposure, State Government Ideology and Welfare Expenditure in U.S. States, 1987-2008

\begin{tabular}{|c|c|c|c|}
\hline & $\begin{array}{l}\text { Model (1) } \\
\Delta \text { Welfare }\end{array}$ & $\begin{array}{l}\text { Model (2) } \\
\text { A Highway }\end{array}$ & $\begin{array}{c}\text { Model (3) } \\
\Delta \text { Education }\end{array}$ \\
\hline Variables & $b$ (Stand.Err.) & $b$ (Stand.Err.) & $b$ (Stand.Err.) \\
\hline Lagged dependent variable & $\begin{array}{l}-0.037 \\
(0.025) \\
\end{array}$ & $\begin{array}{l}-0.064 * * \\
(0.024) \\
\end{array}$ & $\begin{array}{c}0.011 \\
(0.022) \\
\end{array}$ \\
\hline First-difference, trade exposure & $\begin{array}{l}0.027 * \\
(0.014)\end{array}$ & $\begin{array}{c}0.0001 \\
(0.007)\end{array}$ & $\begin{array}{l}0.051 * * \\
(0.018)\end{array}$ \\
\hline Lagged trade exposure & $\begin{array}{l}-0.016 * \\
(0.007) \\
\end{array}$ & $\begin{array}{l}-0.010 * \\
(0.005) \\
\end{array}$ & $\begin{array}{r}0.0006 \\
(0.010) \\
\end{array}$ \\
\hline $\begin{array}{l}\text { First-difference, state government } \\
\text { ideology }\end{array}$ & $\begin{array}{l}-9.87 \mathrm{e}-06 \\
(0.0008)\end{array}$ & $\begin{array}{l}-0.0003 \\
(0.0004)\end{array}$ & $\begin{array}{l}-0.0007 \\
(0.0009) \\
\end{array}$ \\
\hline Lagged state government ideology & $\begin{array}{l}0.0002 * \\
(0.0005)\end{array}$ & $\begin{array}{l}-0.001 * \\
(0.0004) \\
\end{array}$ & $\begin{array}{c}0.0004 \\
(0.0008) \\
\end{array}$ \\
\hline $\begin{array}{l}\text { First-difference trade exposure } \times \\
\text { first-difference liberalism }\end{array}$ & $\begin{array}{c}0.001 \\
(0.001) \\
\end{array}$ & $\begin{array}{l}-0.003 \\
(0.0004) \\
\end{array}$ & $\begin{array}{l}0.002+ \\
(0.001) \\
\end{array}$ \\
\hline $\begin{array}{l}\text { Lagged trade exposure } \times \text { lagged } \\
\text { liberalism }\end{array}$ & $\begin{array}{l}0.0002 * \\
(0.0009)\end{array}$ & $\begin{array}{r}0.0001 * \\
(0.00006)\end{array}$ & $\begin{array}{r}0.00009 \\
(0.0001)\end{array}$ \\
\hline First-difference, unemployment & $\begin{array}{l}0.087 * * * \\
(0.022)\end{array}$ & $\begin{array}{c}0.012 \\
(0.008) \\
\end{array}$ & $\begin{array}{c}0.038 \\
(0.023) \\
\end{array}$ \\
\hline Lagged unemployment & $\begin{array}{c}0.020 \\
(0.013) \\
\end{array}$ & $\begin{array}{l}-0.004 \\
(0.005) \\
\end{array}$ & $\begin{array}{l}-0.029 * \\
(0.012) \\
\end{array}$ \\
\hline First difference, $\%$ black & $\begin{array}{c}0.082 \\
(0.066) \\
\end{array}$ & $\begin{array}{l}-0.005 \\
(0.027) \\
\end{array}$ & $\begin{array}{l}-0.025 \\
(0.069) \\
\end{array}$ \\
\hline Lagged \% black & $\begin{array}{l}6.07 e-06 \\
(0.0007) \\
\end{array}$ & $\begin{array}{l}-0.0007 \\
(0.0006) \\
\end{array}$ & $\begin{array}{l}-0.0005 \\
(0.0008) \\
\end{array}$ \\
\hline $\begin{array}{l}\text { First difference, real per capita } \\
\text { income }\end{array}$ & $\begin{array}{l}0.226 * \\
(0.111) \\
\end{array}$ & $\begin{array}{l}-0.022 \\
(0.061) \\
\end{array}$ & $\begin{array}{l}-0.053 \\
(0.126) \\
\end{array}$ \\
\hline Lagged real per capita income & $\begin{array}{l}-0.003 \\
(0.004) \\
\end{array}$ & $\begin{array}{c}0.002 \\
(0.002) \\
\end{array}$ & $\begin{array}{c}0.008 \\
(0.005) \\
\end{array}$ \\
\hline First difference, per capita growth & $\begin{array}{l}-0.089 * \\
(0.037) \\
\end{array}$ & $\begin{array}{c}0.005 \\
(0.020) \\
\end{array}$ & $\begin{array}{c}0.0006 \\
(0.042) \\
\end{array}$ \\
\hline Lagged per capita growth & $\begin{array}{l}-0.097 * \\
(0.040) \\
\end{array}$ & $\begin{array}{c}0.005 \\
(0.021) \\
\end{array}$ & $\begin{array}{c}0.012 \\
(0.045) \\
\end{array}$ \\
\hline First difference, total roads & $\begin{array}{l}-0.590 \\
(0.769) \\
\end{array}$ & $\begin{array}{l}-0.101 \\
(0.290) \\
\end{array}$ & $\begin{array}{l}-1.499 \\
(0.908)\end{array}$ \\
\hline Lagged total roads & $\begin{array}{l}-0.022 \\
(0.080)\end{array}$ & $\begin{array}{l}-0.045 \\
(0.040) \\
\end{array}$ & $\begin{array}{l}-0.111 \\
(0.078)\end{array}$ \\
\hline First difference, license tax & $\begin{array}{c}0.251 \\
(0.203) \\
\end{array}$ & $\begin{array}{c}0.143 \\
(0.090) \\
\end{array}$ & $\begin{array}{l}0.643 * * \\
(0.226)\end{array}$ \\
\hline Lagged license tax & $\begin{array}{c}0.083 \\
(0.118) \\
\end{array}$ & $\begin{array}{l}-0.013 \\
(0.049) \\
\end{array}$ & $\begin{array}{l}-0.020 \\
(0.104) \\
\end{array}$ \\
\hline First difference, \% under 18 & $\begin{array}{l}-0.017 \\
(0.039)\end{array}$ & $\begin{array}{l}-0.008 \\
(0.017) \\
\end{array}$ & $\begin{array}{c}0.004 \\
(0.046) \\
\end{array}$ \\
\hline Lagged \% under 18 & $\begin{array}{l}-0.002 \\
(0.004)\end{array}$ & $\begin{array}{c}0.002 \\
(0.003) \\
\end{array}$ & $\begin{array}{l}-0.003 \\
(0.006) \\
\end{array}$ \\
\hline $\begin{array}{l}\text { First difference, female labor force } \\
\text { participation }\end{array}$ & $\begin{array}{l}-0.023 * * \\
(0.007) \\
\end{array}$ & $\begin{array}{r}0.0002 \\
(0.004) \\
\end{array}$ & $\begin{array}{l}-0.017 * \\
(0.009) \\
\end{array}$ \\
\hline $\begin{array}{l}\text { Lagged female labor force } \\
\text { participation }\end{array}$ & $\begin{array}{l}-0.003 \\
(0.003) \\
\end{array}$ & $\begin{array}{l}-0.002 \\
(0.001)\end{array}$ & $\begin{array}{l}-0.006 * \\
(0.003)\end{array}$ \\
\hline Constant & $\begin{array}{c}0.429 \\
(0.317) \\
\end{array}$ & $\begin{array}{c}0.177 \\
(0.140) \\
\end{array}$ & $\begin{array}{c}0.357 \\
(0.268) \\
\end{array}$ \\
\hline $\mathrm{N}$ & 1025 & 1025 & 1025 \\
\hline R2 & 0.1749 & 0.0561 & 0.1676 \\
\hline Wald $\chi^{2}$ & 54.04 & 31.24 & 51.31 \\
\hline
\end{tabular}




\section{Appendix 1. Description of Variables}

\begin{tabular}{|c|c|c|}
\hline Variable name & Definition & Data source \\
\hline Welfare spending & State government welfare expenditure as a \% of GSP & $\begin{array}{l}\text { State and Local Government Finance, US Census } \\
\text { (http://www.census.gov/govs/state/) }\end{array}$ \\
\hline Infrastructure spending & State government highway expenditure as a \% of GSP & $\begin{array}{l}\text { State and Local Government Finance, US Census } \\
\text { (http://www.census.gov/govs/state/) }\end{array}$ \\
\hline Education spending & State government education expenditure as a \% of GSP & $\begin{array}{l}\text { State and Local Government Finance, US Census } \\
\text { (http://www.census.gov/govs/state/) }\end{array}$ \\
\hline Trade exposure & Manufacturing exportation as a \% of GSP & $\begin{array}{l}\text { Foreign Trade Division of the Department of Commerce, US Census } \\
\text { (http://www.census.gov/foreign-trade/statistics/state/) }\end{array}$ \\
\hline State government ideology & $\begin{array}{l}\text { Collective ideological orientation of state legislators and } \\
\text { governors }\end{array}$ & Berry et al. (1996) \\
\hline $\begin{array}{l}\text { State government ideology } \\
\text { (Shor \& McCarty 2011) }\end{array}$ & State legislators’ ideology & Shor and McCarty (2011) \\
\hline Unemployment & $\%$ of state population that are unemployed & US Census Bureau Statistics Abstract \\
\hline$\%$ Black & $\%$ of state population that are African Americans & US Census Bureau Statistics Abstract \\
\hline Real per capita income & Deflated per capita income & Bureau of Economic Analysis \\
\hline Per capita growth & $\begin{array}{l}\text { (Real per capita income in the current year-real per capita } \\
\text { income in last year)/real per capita income last year }\end{array}$ & Bureau of Economic Analysis \\
\hline Total roads & Total length of public roads & $\begin{array}{l}\text { US Department of Transportation Federal Highway Administration } \\
\text { (http://www.fhwa.dot.gov/) }\end{array}$ \\
\hline License tax & Motor vehicle and operators license tax & $\begin{array}{l}\text { State and Local Government Finance, US Census } \\
\text { (http://www.census.gov/govs/state/) }\end{array}$ \\
\hline \% under 18 & $\%$ of state population that is under 18 years old & US Census Bureau Statistics Abstract \\
\hline $\begin{array}{l}\text { Female labor force } \\
\text { participation }\end{array}$ & $\%$ of employment among female civilian labor force & US Census Bureau Statistics Abstract \\
\hline
\end{tabular}


Appendix 2. Descriptive Statistics of Key Variables

\begin{tabular}{llllll}
\hline Variables & No. of Obs. & Mean & Std. Dev. & Min & Max \\
\hline Welfare Spending & 1078 & 2.43 & 0.86 & 0.79 & 5.51 \\
Infrastructure Spending & 1078 & 0.99 & 0.41 & 0.35 & 3.21 \\
Education Spending & 1078 & 3.79 & 1.04 & 1.45 & 9.42 \\
Trade Exposure & 1076 & 4.87 & 2.71 & 0.28 & 20.6 \\
State Gov. Ideology & 1078 & 50.3 & 26.1 & 0.00 & 97.9 \\
Unemployment & 1078 & 5.14 & 1.42 & 2.20 & 11.3 \\
\% Black & 1078 & 10.1 & 9.45 & 0.25 & 37.2 \\
Real per capita income & 1078 & 32.9 & 4.13 & 22.4 & 46.6 \\
Per capita growth & 1078 & 1.30 & 2.05 & -9.36 & 16.6 \\
Total roads & 1100 & 0.16 & 0.11 & 0.004 & 0.65 \\
License taxes & 1078 & 0.18 & 0.10 & 0 & 0.92 \\
\% under 18 & 1078 & 25.6 & 2.40 & 20.70 & 39.06 \\
Female labor force participation & 1078 & 60.2 & 4.54 & 40.40 & 71.2 \\
\hline
\end{tabular}




\section{References}

Albritton, R. B. (1990). Social services: Welfare and health. In V. Gray, H. Jacob \& R. Albritton (Eds.), Politics in the American states. Glenview, IL: Scott, Foresman/Little Brown.

Aschauer, D. A. (1991). Infrastructure: America's third deficit. Challenge, 34(2), 39-45. doi: $10.2307 / 40721238$

Bartels, L. (2008). Unequal democracy: The political economy of the new gilded age. New Jersey: Princeton University Press.

Beck, N., \& Katz, J. N. (1995). What to do (and not to do) with time-series cross-section data. American Political Science Review, 89, 634-647.

Beck, N., \& Katz, J. N. (1996). Nuisance versus substance: Specifying and estimating time-series corss-section models. Political Analysis, 6, 1-36.

Berry, W. D., Fording, R. C., Ringquist, E. J., Hanson, R. L., \& Klarner, C. (2013). A new measure of state government ideology, and evidence that both the new measure and an old measure are valid. State Politics \& Policy Quarterly, 13, 164-182.

Berry, W. D., Ringquist, E. J., Fording, R. C., \& Hanson, R. L. (1998). Measuring citizen and government ideology in the American states, 1960-93. American Journal of Political Science, 42, 327-348.

Boix, C. (1998). Political parties, growth and equality. Cambridge: Cambridge University Press.

Boix, C. (2004). Between protectionism and compensation: The political economy of trade. In P. Bardhan, S. Bowles \& M. Wallerstein (Eds.), Globalization and egalitarian redistribution. Washington: Russell Sage Foundation.

Brown, R. D. (1995). Party cleavages and welfare effort in the American states. The American Political Science Review, 89, 23-33. doi: 10.2307/2083072 
Burgoon, B. (2001). Globalization and welfare compensation: Disentangling the ties that bind. International Organization, 55, 509-551.

Busemeyer, M. R. (2007). Determinants of public education spending in 21 oecd democracies, 1980-2001. Journal of European Public Policy, 14, 582-610.

Cameron, D. R. (1978). The expansion of the public economy: A comparative analysis. The American Political Science Review, 72, 1243-1261.

De Boef, S. (2001). Modeling equilibrium relationships: Error correction models with strongly autoregressive data. Political Analysis, 9, 78-94.

De Boef, S., \& Granato, J. (1997). Near-integrated data and the analysis of political relationships. American Journal of Political Science, 41, 619-640.

De Boef, S., \& Keele, L. (2008). Taking time seriously. American Journal of Political Science 52, 184-200.

Dehejia, V. H., \& Genschel, P. (1999). Tax competition in the European Union. Politics \& Society, 27, 403-430.

Dickey, D. A., \& Fuller, W. A. (1979). Distribution of the estimators for autoregressive time series with a unit root. Journal of the American Statistical Association, 74, 427-431.

Ehrlich, S. D. (2007). Access to protection: Domestic institutions and trade policy in democracies. International Organization, 61, 571-605.

Empire State Development. (2011). Business programs. www.esd.ny.gov/BusinessPrograms.html Retrieved January 1, 2015

Erikson, R. S., Wright, G. C., \& McIver, J. P. (1993). Statehouse democracy: Public opinion and policy in the American states. Cambridge: Cambridge University Press. 
Federation of Tax Administrators. (2013). State corporate income tax rates 2013. www.taxadmin.org/fta/rate/corp_inc.pdf Retrieved January 1, 2015

Fellowes, M. C., \& Rowe, G. (2004). Politics and the new American welfare state. American Journal of Political Science, 48, 362-373.

Fishell, D., \& Moretto, M. (2014, September 5, 2014). Is Maine more ‘business friendly’ today under gov. Paul Lepage?, Bangor Daily News.

Gans-Morse, J., \& Nichter, S. (2008). Economic reforms and democracy: Evidence of a j-curve in Latin America. Comparative Political Studies, 41, 1398-1426.

Garand, J. (1988). Explaining government growth in the U.S. States. The American Political Science Review, 82, 837-849. doi: 10.2307/1962494

Garand, J. (2010). Income inequality, party polarization, and roll-call voting in the U.S. Senate. Journal of Politics, 72, 1109-1128.

Garand, J. C. (1985). Partisan change and shifting expenditure priorities in the American states, 1945-1978. American Politics Quarterly, 13, 355-392.

Garrett, G. (1995). Capital mobility, trade, and the domestic politics of economic policy. International Organization, 49, 657-687. doi: 10.1017/S0020818300028472

Garrett, G. (1998). Global markets and national politics: Collision course or virtuous circle? International Organization, 52, 787-824. doi: 10.2307/2601358

Garrett, G. (2001). Globalization and government spending around the world. Studies in Comparative International Development, 35(4), 3-29.

Garrett, G., \& Mitchell, D. (2001). Globalization, government spending and taxation in the OECD. European Journal of Political Research, 39, 145-177. 
Garrett, G., \& Rodden, J. (2001). Globalization and fiscal decentralization. Paper presented at the Globalization and Governance, The Grande Colonial Hotel, La Jolla, CA.

Genschel, P. (2002). Globalization, tax competition, and the welfare state. Politics \& Society, 30, 245-275. doi: 10.1177/0032329202030002003

Genschel, P. (2004). Globalization and the welfare state: A retrospective. Journal of European Public Policy, 11, 613-636.

Gilens, M. (1996). 'Race-coding’ and white opposition to welfare. American Political Science Review, 90, 593-604.

Haupt, A. B. (2010). Parties' responses to economic globalization: What is left for the left and right for the right? Party Politics, 16, 5-27. doi: 10.1177/1354068809339535

Hero, R. E., \& Preuhs, R. R. (2007). Immigration and the evolving American welfare state: Examining policies in the U.S. States. American Journal of Political Science 51, 498-517.

Hetherington, M. J. (2009). Review article: Putting polarization in perspective. British Journal of Political Science 39, 413-448.

Huber, E., \& Stephens, J. D. (2001). Development and crisis of the welfare state : Parties and policies in global markets. Chicago: The University of Chicago Press.

Iversen, T., \& Cusack, T. R. (2000). The causes of welfare state expansion: Deindustrialization or globalization? World Politics, 52, 313-349.

Katzenstein, P. J. (1985). Small states in world markets : Industrial policy in Europe. Ithaca, N.Y.: Cornell University Press.

Kelly, N. J., \& Witko, C. (2012). Federalism and american inequality. Journal of Politics, 74, 414426. 
King, G., Tomz, M., \& Wittenberg, J. (2000). Making the most of the statistical analysis. American Journal of Political Science, 44, 341-355.

Korpi, W., \& Palme, J. (2003). New politics and class politics in the context of austerity and globalization: Welfare state regress in 18 countries, 1975-95. The American Political Science Review, 97, 425-446. doi: 10.2307/3117618

Lewis-Beck, M. S., \& Rice, T. W. (1985). Government growth in the United States. The Journal of Politics, 47, 2-30. doi: 10.2307/2131063

Lijphart, A. (1971). Comparative politics and the comparative method. American Political Science Review, 65, 682-693.

Lowery, D., \& Berry, W. D. (1983). The growth of government in the United States: An empirical assessment of competing explanations. American Journal of Political Science, 27, 665-694. doi: $10.2307 / 2110888$

Lowery, D., Konda, T., \& Garand, J. (1984). Spending in the states: A test of six models. Western Political Quarterly, 37, 48-66.

Lynch, J. (2006). Age in the welfare state: The origins of social spending on pensioners, workers, and children. New York, NY: Cambridge University Press.

McCarty, N., Poole, K., \& Rosenthal, H. (2006). Polarized America : The dance of ideology and unequal riches. Cambridge, Mass.: MIT Press.

Montinola, G., Qian, Y., \& Weingast, B. R. (1995). Federalism, Chinese style: The political basis for economic success in china. World Politics, 48, 50-81.

Mosley, L. (2005). Globalisation and the state: Still room to move? New Political Economy, 10, 355-362. doi: 10.1080/13563460500204241 
Persyn, D., \& Westerlund, J. (2008). Error correction based cointegration tests for panel data. Stata Journal, 8, 232-241.

Phillips, P. C. B., \& Perron, P. (1988). Testing for a unit root in time series regression. Biometrika, 75, 335-346.

Piven, F. F. (2001). Globalization, American politics, and welfare policy. Annals of the American Academy of Political and Social Science, 577, 26-37. doi: 10.2307/1049820

Rodrik, D. (1998). Why do more open economies have bigger governments? Journal of Political Economy, 106, 997-1032.

Rudra, N. (2002). Globalization and the decline of the welfare state in less-developed countries. International Organization, 56, 411-445. doi: 10.2307/3078610

Rudra, N., \& Haggard, S. (2005). Globalization, democracy, and effective welfare spending in the developing world. Comparative Political Studies, 38, 1015-1049. doi: 10.1177/0010414005279258

Scheve, K., \& Slaughter, M. J. (2004). Economic insecurity and the globalization of production. American Journal of Political Science, 48, 662-674. doi: 10.2307/1519926

Schmitt, C., \& Starke, P. (2011). Explaining convergence of oecd welfare states: A conditional approach. Journal of European Social Policy, 21, 120-135.

Schuster, P., Schmitt, C., \& Traub, S. (2013). The retreat of the state from entrepreneurial activities: A convergence analysis for oecd countries, 1980-2007. European Journal of Political Economy, 32, 95-112.

Shor, B., \& McCarty, N. (2011). The ideological mapping of American legislatures. American Political Science Review, 105, 530-551. 
Soss, J., Schram, S., Vartanian, T., \& O'Brien, E. (2001). Setting the terms of relief: Explaining state policy choices in the devolution revolution. American Journal of Political Science, 45, 378-395.

Swank, D. (2005). Globalisation, domestic politics, and welfare state retrenchment in capitalist democracies. Social Policy and Society, 4, 183-195. doi: 10.1017/S1474746404002337

Swank, D., \& Steinmo, S. (2002). The new political economy of taxation in advanced capitalist democracies. American Journal of Political Science 46, 642-655.

Tufte, E. R. (1980). Political control of the economy. New Jersey: Princeton University Press.

Wagner, A. (1877). Finanzwissenschaft pt i. Leipzig: C.F. Winter.

Walter, S. (2010). Globalization and the welfare state: Testing the microfoundations of the compensation hypothesis. International Studies Quarterly, 54, 403-426. doi:

10.1111/j.1468-2478.2010.00593.x

Weingast, B. R. (1995). The economic role of political institutions: Market-preserving federalism and economic development. Journal of Law, Economics, \& Organization, 11, 1-31.

Westerlund, J. (2007). Testing for error correction in panel data. Oxford Bulletin of Economics and Statistics, 69, 709-748.

Wood, A. (1994). North-south trade, employment, and inequality: Changing fortunes in a skilldriven world. Oxford, U.K.: Clarendon Press. 
${ }^{1}$ States use many approaches to attract and retain businesses that are involved in international trade. A few examples are offered in this note. New York has a series of corporate assistance programs under the agency umbrella, Empire State Development (ESD). The ESD website states its main goal as to "provide a variety of assistance aimed at helping businesses; whether you are an international company looking to make a move or a small business owner wanting to access capital.” Perhaps most relevant for our research is ESD’s New York State’s Manufacturing Assistance Program (MAP), which is a subsidy program that provides export intensive manufacturers subsidized financing to help improve production, productivity and competitiveness. The program is only available to export intensive manufacturers and is explicitly designed to help grow export manufacturing within the state. Though not restricted to manufacturers, New York has for decades offered direct tax credits for businesses that remain or relocate to the state through its Empire Zone Program (Empire State Development, 2011).

Governor Paul LePage of Maine ran his campaign on reduced taxes, lower or eliminated corporate fees, and streamlined regulations in an explicit effort to grow Maine businesses. He even hung a sign on a Maine highway stating that Maine is now "open for business.” LePage is perhaps best known for consulting with state manufacturers and then directing the state Department of Environmental Protection (DEM) to loosen many environmental regulations and procedures, such as the controversial decision to exclude the known carcinogen, formaldehyde, from the list of dangerous chemicals that manufacturers (including children’s toy makers) are required to report in state disclosure documents. Ben Gilman, a representative of the Maine Chamber of Commerce approvingly notes that a "customer-client relationship is in place; I think that's the biggest change [from the past administration]” (Fishell \& Moretto, 2014). 
States, with the power to set corporate tax rates, can create an environment more and less friendly to businesses, as these tax rates can influence global competiveness by increasing the cost of doing business. American states vary a great deal in their corporate tax rate. For example, in 2013, states such as Washington, Wyoming, Nevada, and South Dakota do not charge any corporate income tax, but corporate taxes in states/districts such as D.C., Pennsylvania, and Iowa are as high as 10\% (Federation of Tax Administrators, 2013).

${ }^{2}$ Even Piven, who holds a normatively negative view of "market preserving federalism," agrees that U.S. states strive to keep businesses engaged in the international market satisfied. According to his essay connecting globalization to state welfare policy, American states "are acutely sensitive to the threat that mobile businesses will leave the state if they fail to win their demands from the state government” (2001, 26, 30). Regardless of their normative differences, a diversity of perspectives makes clear that free trade policy set at the national level is just one way that governments in the United States can attract, grow, or maintain businesses engaged in international trade.

Indeed, even in heavily centralized China, where trade policy is set at the nation state level, Montinola, Qian, and Weingast demonstrate that small degrees of fiscal decentralization can be used to attract foreign capital: "There is also considerable competition among regionsprovinces, townships, cities, special economic zones, and developmental zones—for foreign capital” with local "laws, regulations, and taxes that promote economic development" representing the key ways that Chinese "local governments try to attract foreign investment or business” $(1995,77)$.

${ }^{3}$ See online appendix 1 and 2 for over-time and cross-state variation in trade. 
${ }^{4}$ American state governments also offer a wide range of government ideologies (Garand, 1985; Berry, Ringquist, Fording, \& Hanson, 1998; Kelly \& Witko, 2012), the spectrum of which largely resembles the left-right government ideologies from a cross-national perspective (Garand, 1985; Berry et al., 1998; Kelly \& Witko, 2012). In addition, the states have discretion over social safety net programs and other forms of government spending (Lowery, Konda, \& Garand, 1984; Garand, 1985; Garand, 1988; Albritton, 1990; Erikson, Wright, \& McIver, 1993).

${ }^{5}$ For the efficiency school, economic globalization leads to "footloose capital." Production and capital can enter and exit countries, with the primary motivator being lower costs (Rudra 2002; Garrett 1998; Genschel 2004). Dehejia and Genschel vividly describe how “footloose capital” under globalization affects government spending: “capital owners can avoid high taxes by shifting their assets to low-tax countries: exit becomes a viable option and a credible implicit threat. Governments can no longer adjust the tax burden to the revenue needs of the welfare state, but must take foreign tax policy into consideration. If domestic taxes are higher than elsewhere, capital flight results. Relatively low taxes, by contrast, may attract foreign capital. This lures governments into a competition for lower tax rates and pushes the effective burden on capital down to ever lower levels” (Dehejia and Genschel 1999: 403).

${ }^{6}$ The models were re-run with a measure of state-level total exports as the independent variable and the results were largely the same in terms of substance and significance.

${ }^{7}$ The online appendix includes the details regarding the Dickey-Fuller and Westerlund tests that assess the presence of stationarity and cointegration respectively.

${ }^{8}$ Trade exposure has both a short- and long-run effect on welfare spending. In the body of this paper we focus on the long term effects. The short-term effect of trade exposure, according to De Boef and Keele (2008), is reflected by the coefficient of first-order difference of trade exposure, 
0.028. In other words, every percentage point increase in trade exposure this year will lead to 0.028 percentage point increase in welfare expenditure as a percentage of the GSP next year. ${ }^{9}$ For display purposes we use the $5^{\text {th }}$ percentile value of state government ideology as an example of very conservative state governments, and the $95^{\text {th }}$ percentile value of state government ideology as an example of very liberal state governments.

10 Trade exposure does not seem to have a short-run effect on infrastructure spending since the coefficient of first-difference trade exposure is not statistically significant.

${ }^{11}$ Overall, the United States economy traditionally has had a much lower reliance on trade and also regularly is the Anglo/liberal democracy with the lowest levels of social spending (Garrett 2001). Rudra (2002) makes a similar argument that the best known globalization theories and studies do not always apply to developing economies that lack these social democratic institutions.

12 Though not the focus of this research, it is worth noting that trade exposure does have a positive short-run effect on education spending. 


\section{Online Appendix}

Appendix 1. Trade exposure variation across states and over time
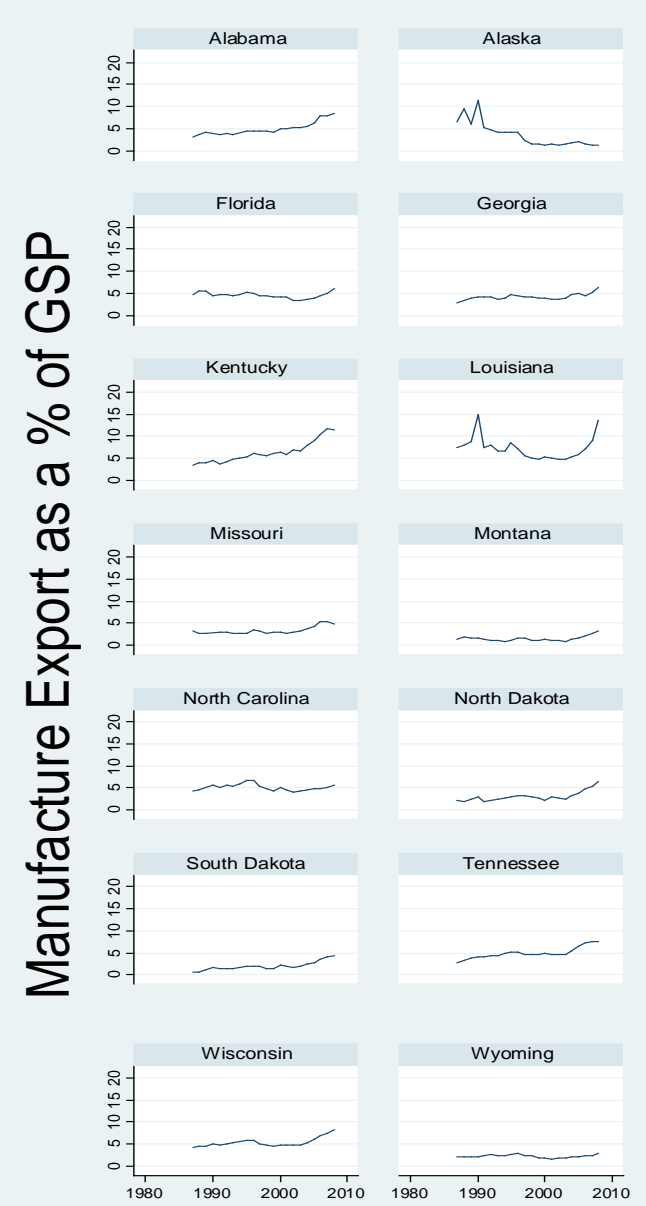

Graphs by State Name
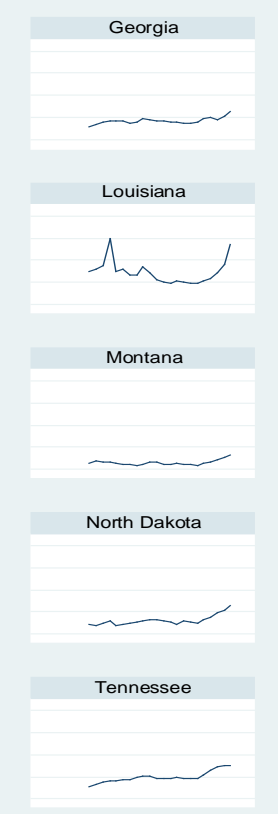
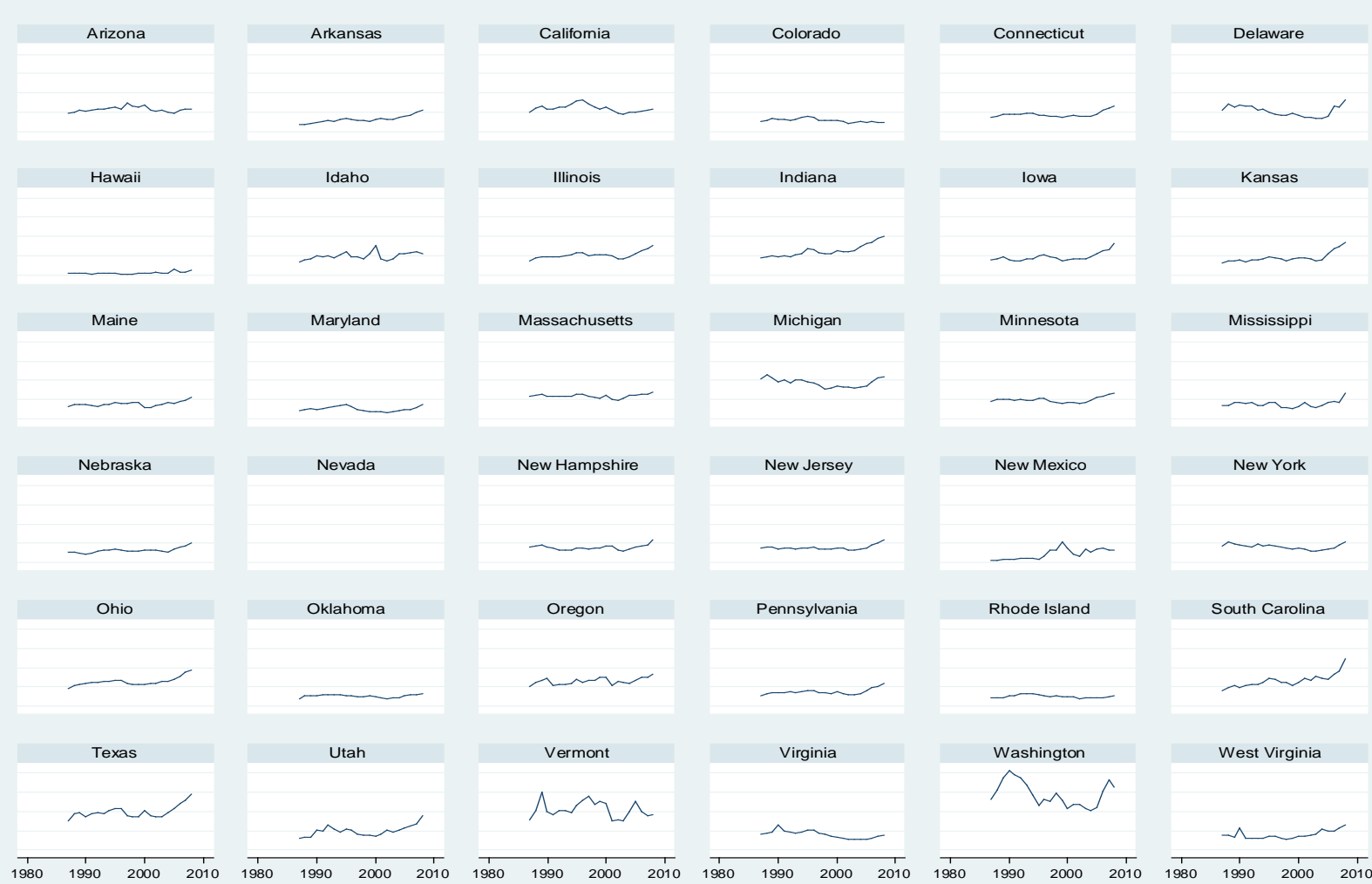

Utah
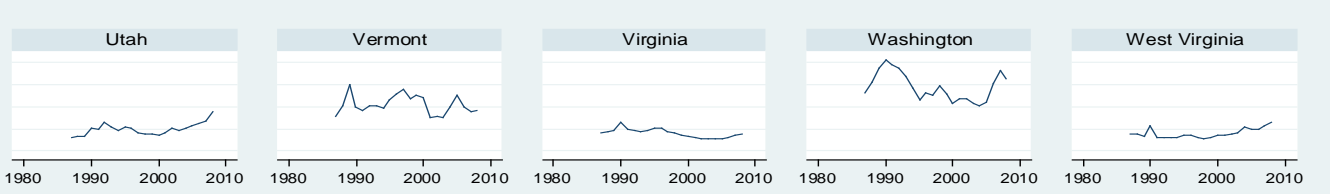

\section{year}


Appendix 2. Trade exposure for American states in 1987 and 2008

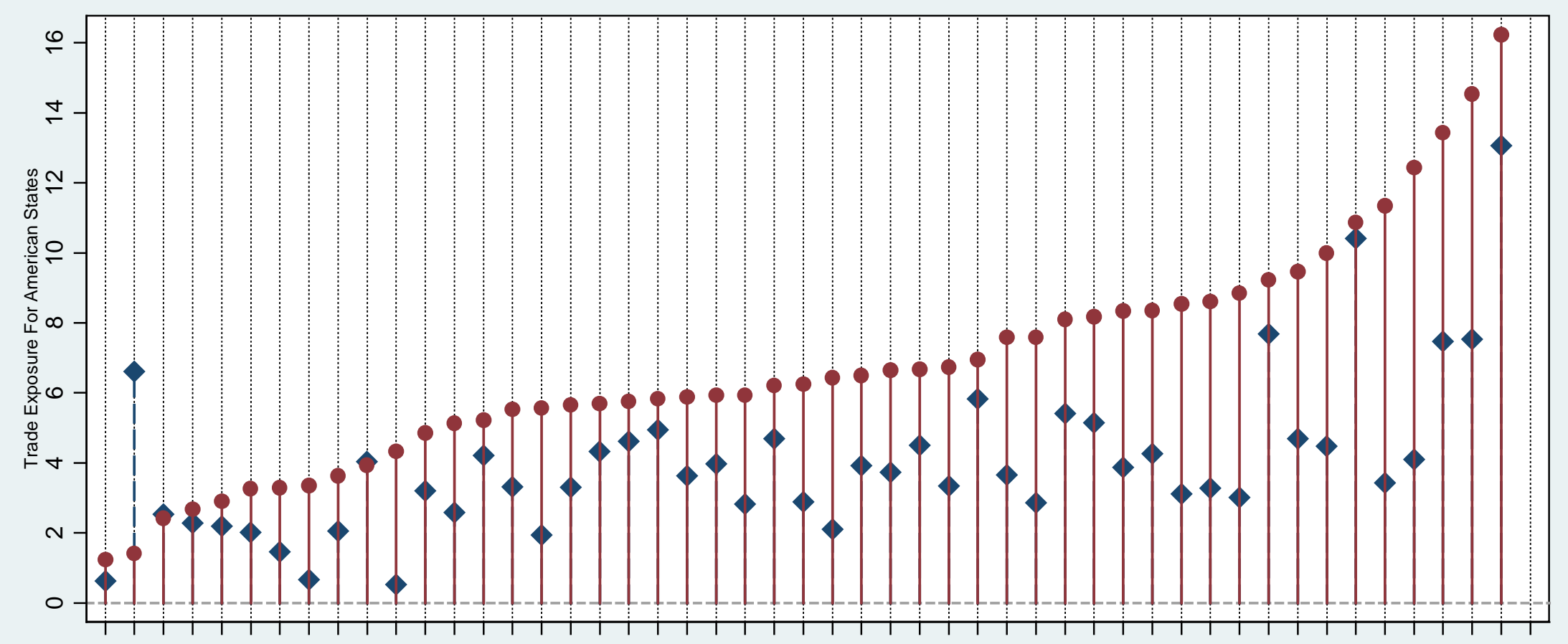

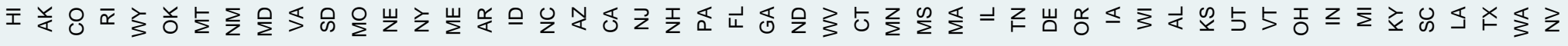




\begin{tabular}{|c|c|c|c|}
\hline & $\begin{array}{l}\text { Model (1) } \\
\Delta \text { Welfare }\end{array}$ & $\begin{array}{l}\text { Model (2) } \\
\Delta \text { Highway }\end{array}$ & $\begin{array}{c}\text { Model (3) } \\
\Delta \text { Education }\end{array}$ \\
\hline Variables & $b$ (Stand.Err.) & $b$ (Stand.Err.) & $b$ (Stand.Err.) \\
\hline Lagged dependent variable & $\begin{array}{l}-0.012 \\
(0.033)\end{array}$ & $\begin{array}{l}-0.063+ \\
(0.033)\end{array}$ & $\begin{array}{c}0.039 \\
(0.030)\end{array}$ \\
\hline First-difference, trade exposure & $\begin{array}{l}0.046 * * \\
(0.016)\end{array}$ & $\begin{array}{l}0.019 * \\
(0.009)\end{array}$ & $\begin{array}{l}0.094^{* * *} \\
(0.025)\end{array}$ \\
\hline Lagged trade exposure & $\begin{array}{l}-0.003 \\
(0.005)\end{array}$ & $\begin{array}{l}-0.002 \\
(0.002)\end{array}$ & $\begin{array}{c}0.006 \\
(0.006)\end{array}$ \\
\hline First-difference, state government liberalism & $\begin{array}{l}-0.001+ \\
(0.001)\end{array}$ & $\begin{array}{l}-0.001 * \\
(0.0003)\end{array}$ & $\begin{array}{l}-0.001+ \\
(0.001)\end{array}$ \\
\hline Lagged state government liberalism & $\begin{array}{l}-0.001 \\
(0.0003)\end{array}$ & $\begin{array}{l}-0.001 * * * \\
(0.0003)\end{array}$ & $\begin{array}{l}-0.001 \\
(0.001)\end{array}$ \\
\hline $\begin{array}{l}\text { First-difference trade exposure } \times \text { first-difference } \\
\text { liberalism }\end{array}$ & $\begin{array}{l}-0.001 \\
(0.001)\end{array}$ & $\begin{array}{l}-0.0003 \\
(0.001)\end{array}$ & $\begin{array}{r}0.0002 \\
(0.002)\end{array}$ \\
\hline Lagged trade exposure $\times$ lagged liberalism & $\begin{array}{l}-0.0001 * \\
(0.00006)\end{array}$ & $\begin{array}{l}0.0001 * * * \\
(0.00004)\end{array}$ & $\begin{array}{l}-0.0002+ \\
(0.0001)\end{array}$ \\
\hline First-difference, unemployment & $\begin{array}{l}0.061 * \\
(0.026)\end{array}$ & $\begin{array}{c}0.012 \\
(0.012)\end{array}$ & $\begin{array}{l}0.050 \\
(0.035)\end{array}$ \\
\hline Lagged unemployment & $\begin{array}{l}-0.014 \\
(0.015) \\
\end{array}$ & $\begin{array}{l}-0.009 \\
(0.009)\end{array}$ & $\begin{array}{l}-0.053 * * \\
(0.018)\end{array}$ \\
\hline First difference, \% black & $\begin{array}{l}0.033 \\
(0.3)\end{array}$ & $\begin{array}{l}-0.010 \\
(0.029)\end{array}$ & $\begin{array}{l}-0.077 \\
(0.075)\end{array}$ \\
\hline Lagged \% black & $\begin{array}{l}0.000003 \\
(0.001)\end{array}$ & $\begin{array}{l}-0.001 \\
(0.001)\end{array}$ & $\begin{array}{l}-0.0001 \\
(0.001)\end{array}$ \\
\hline First difference, real per capita income & $\begin{array}{l}0.437 * * * \\
(0.128)\end{array}$ & $\begin{array}{l}-0.164 * \\
(0.070)\end{array}$ & $\begin{array}{l}-0.056 \\
(0.188)\end{array}$ \\
\hline Lagged real per capita income & $\begin{array}{l}-0.002 \\
(0.005)\end{array}$ & $\begin{array}{l}0.004+ \\
(0.002)\end{array}$ & $\begin{array}{c}0.009 \\
(0.007)\end{array}$ \\
\hline First difference, per capita growth & $\begin{array}{l}-0.175 \text { *** } \\
(0.048)\end{array}$ & $\begin{array}{c}0.057 * \\
(0.025)\end{array}$ & $\begin{array}{c}0.001 \\
(0.071)\end{array}$ \\
\hline Lagged per capita growth & $\begin{array}{l}-0.186 * * * \\
(0.051)\end{array}$ & $\begin{array}{c}0.054 * \\
(0.025)\end{array}$ & $\begin{array}{c}0.011 \\
(0.076)\end{array}$ \\
\hline First difference, total roads & $\begin{array}{l}-0.254 \\
(0.630)\end{array}$ & $\begin{array}{c}0.119 \\
(0.297)\end{array}$ & $\begin{array}{c}-0.848 \\
(-0.890)\end{array}$ \\
\hline Lagged total roads & $\begin{array}{l}-0.078 \\
(0.107) \\
\end{array}$ & $\begin{array}{l}-0.036 \\
(0.002) \\
\end{array}$ & $\begin{array}{l}-0.100 \\
(0.121)\end{array}$ \\
\hline First difference, license tax & $\begin{array}{c}0.215 \\
(0.206)\end{array}$ & $\begin{array}{c}0.105 \\
(0.096)\end{array}$ & $\begin{array}{c}0.489 * \\
(0.243)\end{array}$ \\
\hline Lagged license tax & $\begin{array}{c}0.142 \\
(0.183)\end{array}$ & $\begin{array}{l}-0.046 \\
(0.056)\end{array}$ & $\begin{array}{l}-0.184 \\
(0.136)\end{array}$ \\
\hline First difference, \% under 18 & $\begin{array}{l}-0.036 \\
(0.048)\end{array}$ & $\begin{array}{l}-0.021 \\
(0.020)\end{array}$ & $\begin{array}{l}-0.019 \\
(0.065)\end{array}$ \\
\hline Lagged \% under 18 & $\begin{array}{l}-0.006 \\
(0.006)\end{array}$ & $\begin{array}{l}-0.002 \\
(0.004)\end{array}$ & $\begin{array}{l}-0.017 * \\
(0.009)\end{array}$ \\
\hline First difference, female labor force participation & $\begin{array}{l}-0.026 * * \\
(0.009)\end{array}$ & $\begin{array}{c}0.006 \\
(0.006)\end{array}$ & $\begin{array}{l}-0.027 * \\
(0.011)\end{array}$ \\
\hline Lagged female labor force participation & $\begin{array}{l}-0.006^{*} \\
(0.006)\end{array}$ & $\begin{array}{l}-0.003 \\
(0.002)\end{array}$ & $\begin{array}{l}-0.007+ \\
(0.004)\end{array}$ \\
\hline Constant & $\begin{array}{c}0.814^{*} \\
(0.344)\end{array}$ & $\begin{array}{c}0.256 \\
(0.203) \\
\end{array}$ & $\begin{array}{c}0.774 * \\
(0.365)\end{array}$ \\
\hline $\mathrm{N}$ & 581 & 581 & 581 \\
\hline $\mathrm{R} 2$ & 0.192 & 0.087 & 0.274 \\
\hline Wald $\chi^{2}$ & 52.99 & 46.54 & 62.85 \\
\hline
\end{tabular}




\section{Appendix 4. Interactive effects when using the Shor \& McCarty measure as an alternative measure of state government ideology}

a. Predicted value of change in welfare spending as trade exposure varies from minimum to maximum values under liberal and conservative state governments (with the Shor \& McCarty measure)

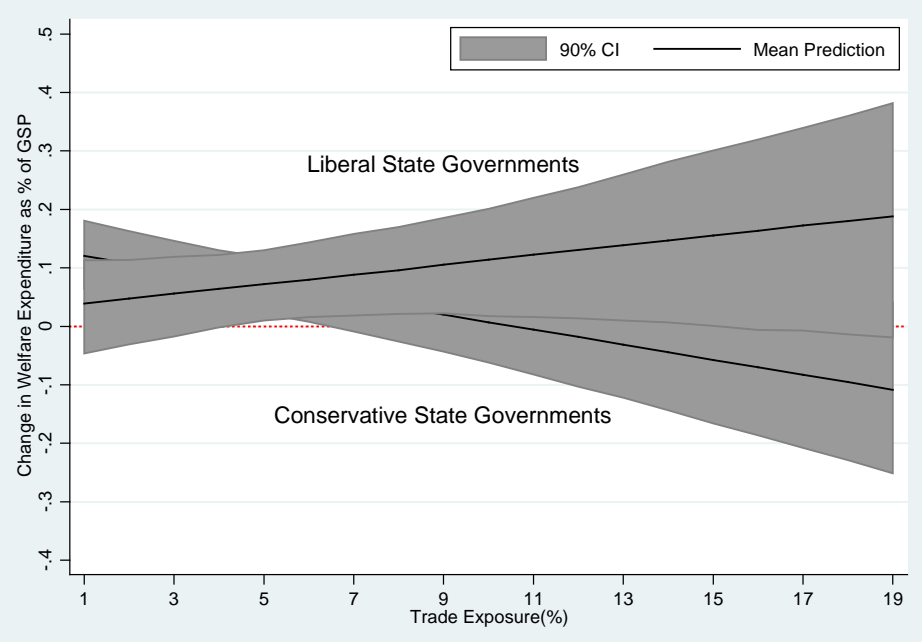

b. Predicted value of change in infrastructure spending as trade exposure varies from minimum to maximum values under liberal and conservative state governments (with the Shor \& McCarty measure)

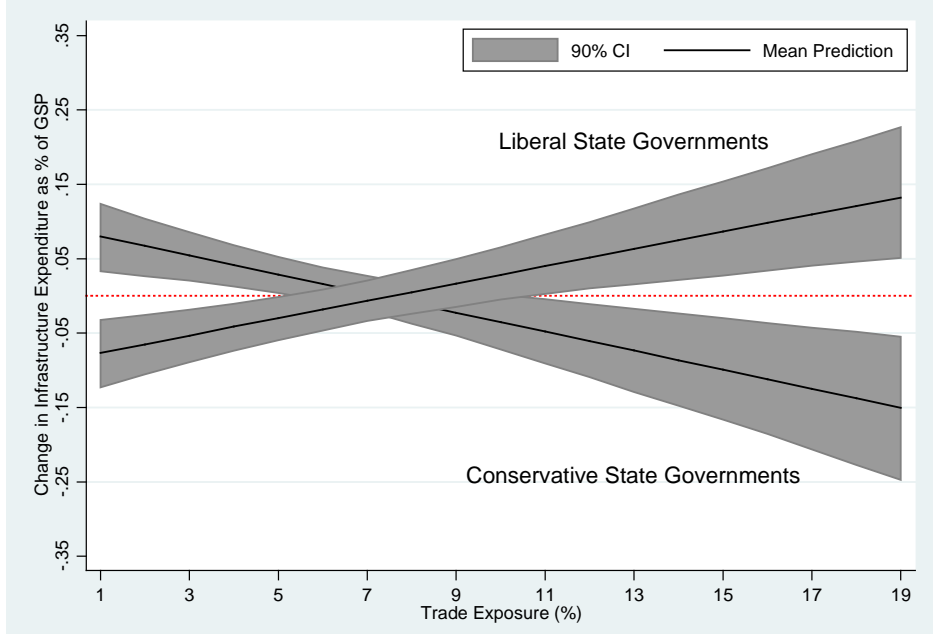




\section{Appendix 5: Cross Sectional and Time Series (CSTS) data analysis diagnosis}

\section{Data Structure}

Our Cross Section and Time Series (CSTS) data contain 49 states and 22 years. To observe the characteristics of our dependent variables we use "welfare spending as a \% of GSP” as a representative illustration. The same diagnosis has been done on the other two dependent variables, i.e., infrastructure spending as a \% of GSP and education spending as a \% of GSP. Results of diagnoses on the other two dependent variables show similar patterns and can be obtained upon request.

Below Figure 1 demonstrates the variation of welfare expenditure as a \% of GSP across states and over time. Over time, welfare expenditure has generally increased across the states, although periods of retrenchment and stagnation seem evident. There are notable differences among 49 states in their welfare expenditure; for instance, states such as New York and West Virginia spent more than 3.5\% of their GSP on welfare on average, whereas states such as Virginia and Wyoming spent on average less than $1.5 \%$ of their GSP on welfare during this time period. Therefore, our CSTS model specification should be able to capture both the over-time and crossstate variation.

\section{OLS, FE and RE Models Comparison}

We start with a simple generic OLS model and the results are presented in Table 1 Model (1). Note that an OLS model assumes complete poolability, which means that the effect of our independent variables on the dependent variable (i.e., welfare expenditure in this case) remains the same across states and over time. If the effect varies across time and units, which is often the case, the coefficients in the OLS model will only reflect the mean effect (i.e., in our situation the mean effect for 49 states and 22 years). The OLS model specification could be problematic in 


\section{Figure 1. Welfare expenditure as a \% of GSP across 49 states and over 22 years}

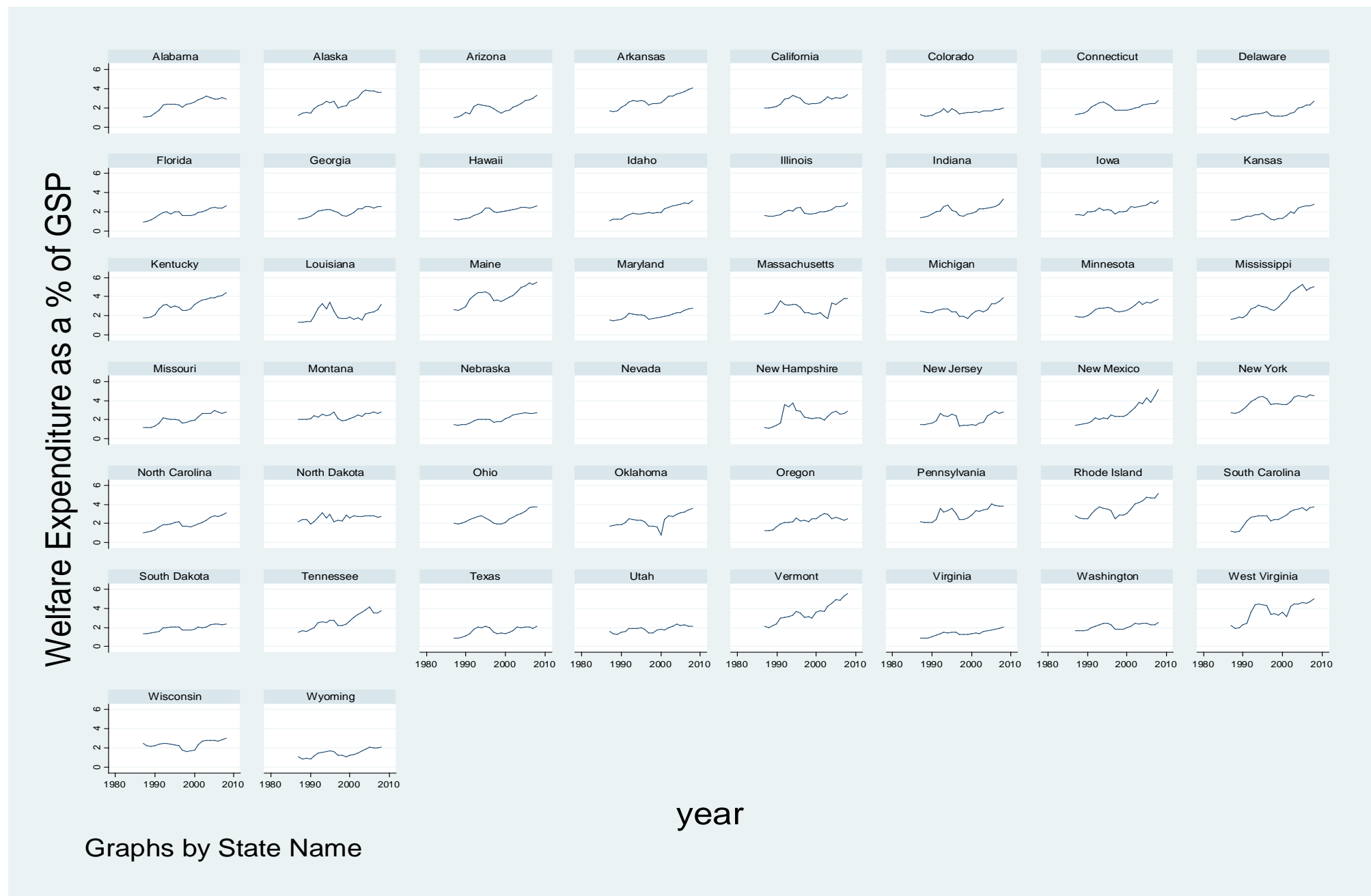


estimating CSTS data because of unit heterogeneity and temporal heterogeneity. Since our CSTS data show notable cross-state and temporal variation, the OLS model is most likely not appropriate for our data.

To test whether OLS is inappropriate, we estimate two fixed effect (FE) models to compare with the OLS model. FE models go beyond OLS by estimating unit-based effects, either by including a full set of unit dummies or mean-centering all the right hand variables (Greene, 2011; Allison, 2009; see also Zhu, 2012). We have estimated both types of fixed effect models. Below Table 1 Model (2) uses the technique of mean-centering the dependent variable, while Table 1 Model (3) includes a full set of state dummies. Comparing results from the OLS (which assumes unit homogeneity) and the two fixed effect models (which assume unit heterogeneity), we notice that coefficients have changed substantially when we move from the OLS model to the FE models. Such differences verify that our data are sensitive to model specification and we reason the differences are owing to the fact that the OLS model is unable to consider unit heterogeneity.

Therefore, we conclude that the results from the FE models are more accurate than the OLS model.

Table 1. OLS, Fixed Effect with Dummies, Fixed Effects with Centering Means, and Random Effect Models.

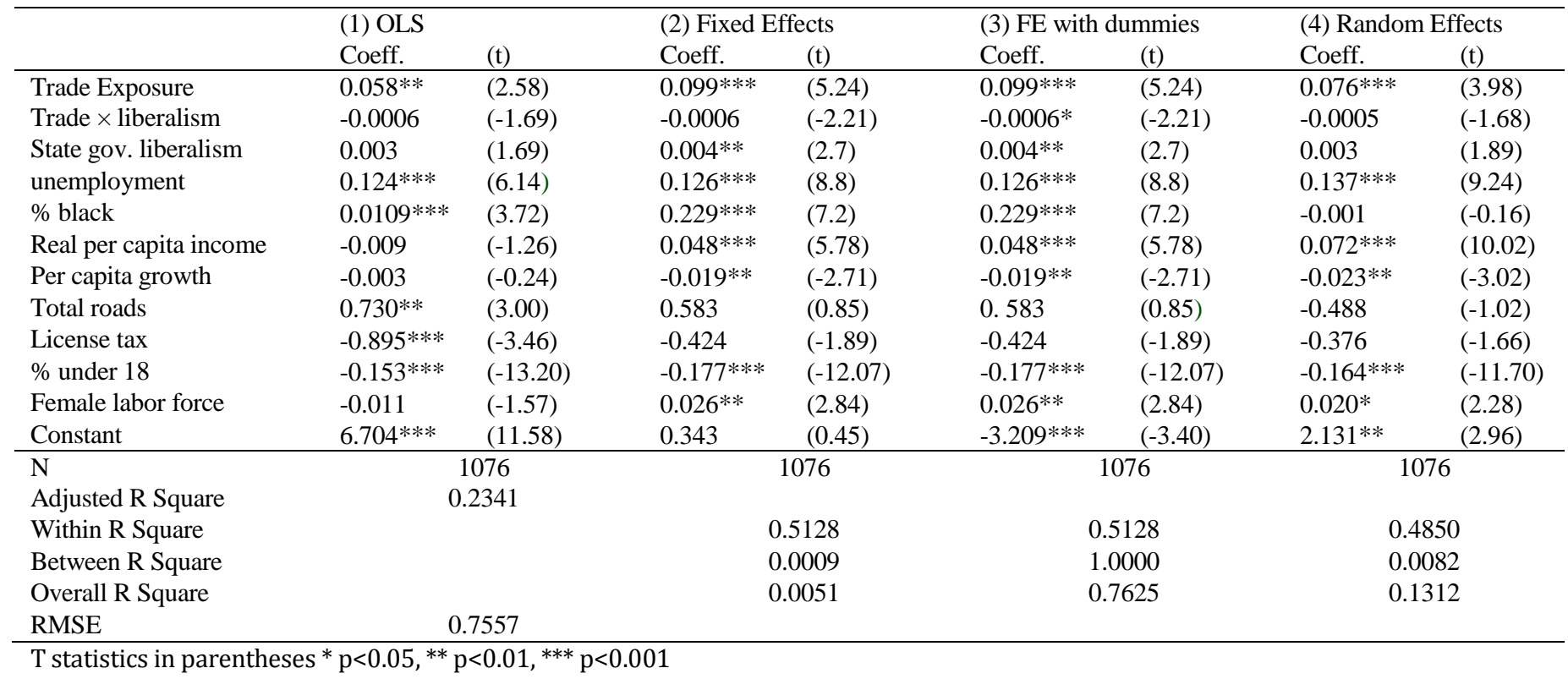


The FE models, although more accurate than OLS, are often criticized because they consume too much cross-sectional variation. In other words, although researchers could tell from the FE models whether or not cross-sectional variation exists, they cannot tell what causes the cross-sectional variation (Zhu, 2012). A core theoretical argument of our paper is that certain political and economic factors (i.e., trade exposure and state government ideology) could explain the cross-state variation of our dependent variable (i.e., government spending), but the state dummies in the FE model might absorb most of the cross-state variation and cause null findings in our independent variables. When we look at the results of the FE models, we discover that Model (3) with the state dummies have a between R-square of 1 . This shows that when we include state dummy variables in Model (3), these dummy variables have indeed absorbed almost all of the cross-state variation.

Unlike the FE models which include state dummies as regressors, the random effects (RE) model includes an intercept that can randomly deviate from a mean intercept. Table 1 Model (4) presents the results of the RE model. Different from the FE model, the RE model leaves room for substantive independent variables to explain cross-state variation without including state dummies. However, this type of model requires that the random intercept does not correlate with the lefthand-side variables; otherwise the RE model estimation will be inconsistent and inefficient. We can use the Hausman test to evaluate whether or not FE and RE models generate consistent and efficient results (Hausman, 1978). The Hausman test, comparing the results of the FE model with the technique of mean-centering the dependent variable and the RE model, generates a chi-square of 50.05 ( $\mathrm{p}=0.000$ ). The result shows that the RE model is not consistent and generates biased estimations. 
In sum, we discover that our data do not have complete poolability, thus OLS is not appropriate. The FE models absorb almost all cross-state variation and the RE model does not generate consistent/efficient results; therefore both the FE and RE models are excluded from consideration.

\section{Temporal dependency of our data}

We also diagnosed the temporal dependency of our dependent variable. Many political and policy variables such as institutions, public policies, and government spending often bear longterm memory or in other words their current value is dependent upon their past values. One important task of panel data analysis is to diagnose whether or not the dependent variable has a stationary process. To explain stationarity mathematically, we use the following equation to specify the relationship between the current and past values of our dependent variable: $\mathrm{Y}_{\mathrm{i}, \mathrm{t}}=\mathrm{a}$ $\times Y_{i, t-1}+e_{i, t}$. In this equation $Y_{i, t}$ is the current value of variable $Y$, while $Y_{i, t-1}$ is the past value for variable $Y$. If $|\mathrm{a}|<1$, the time series of $\mathrm{Y}$ is considered stationary. If $|\mathrm{a}|=1$, the variable is considered to have permanent memories (with a unit-root), or is called non-stationary.

We can use a series of tests (i.e., the Augmented Dickey-Fuller unit-root test, and PhillipsPerron test) to investigate the temporal dependency of our dependent variable (Dickey \& Fuller, 1981; Phillips \& Perron, 1988). In these tests, the null hypothesis is that at least one of the series in the panel data is non-stationary. We have used both the Augmented Dickey-Fuller and PhilipsPerron unit-root tests and have considered a linear term with and without trend, a first-order lag with and without trend, a second-order lag with and without trend. 11 out of 12 tests show strong evidence that our dependent variable "welfare expenditure as a \% of GSP” contains a unit-root. The results of all 12 tests are presented in Table 2 below. 
In order to further verify our unit-root diagnosis, we have also run a correlation between the current value of welfare expenditure $\left(\mathrm{Y}_{\mathrm{t}}\right)$ and the past value of welfare expenditure $\left(\mathrm{Y}_{\mathrm{t}-1}\right)$ for each state. Below Figure 2 shows the correlation coefficients for all 49 states. 48 out of 49 states have significant correlations, and only 1 state (North Dakota) has an insignificant correlation. Except for North Dakota, the mean coefficient is 0.91 , which is close to 1 . In addition, 45 out of 49 states observe a correlation that is not significantly different from 1 . In other words, the current value of our dependent variable is highly dependent upon its past value for the vast majority of states. Using evidence from Table 2 and Figure 2, we are confident that our dependent variable "welfare expenditure as a \% of GSP” has a unit-root and is non-stationary.

Table 2. Unit Root Tests Using Augmented Dickey-Fuller (ADF) and Phillips-Perron (PP) Tests

\begin{tabular}{lll}
\hline Tests & Chi-square & p-value \\
\hline ADF, no trend, lag (0) & 41.510 & 1.000 \\
ADF, no trend, lag (1) & 67.599 & 0.992 \\
ADF, no trend, lag(2) & 92.239 & 0.645 \\
ADF, trend, lag(0) & 32.799 & 1.000 \\
ADF, trend, lag(1) & 68.104 & 0.991 \\
ADF, trend, lag(2) & 136.343 & 0.006 \\
PP, no trend, lag(0) & 41.510 & 1.000 \\
PP, no trend, lag(1) & 44.600 & 1.000 \\
PP, no trend, lag(2) & 47.200 & 1.000 \\
PP, trend, lag(0) & 32.800 & 1.000 \\
PP, trend, lag(1) & 40.450 & 1.000 \\
PP, trend, lag(2) & 45.800 & 1.000 \\
\hline
\end{tabular}


Figure 2. First-order Correlation between Welfare Expenditure (t) and Welfare Expenditure (t-1).

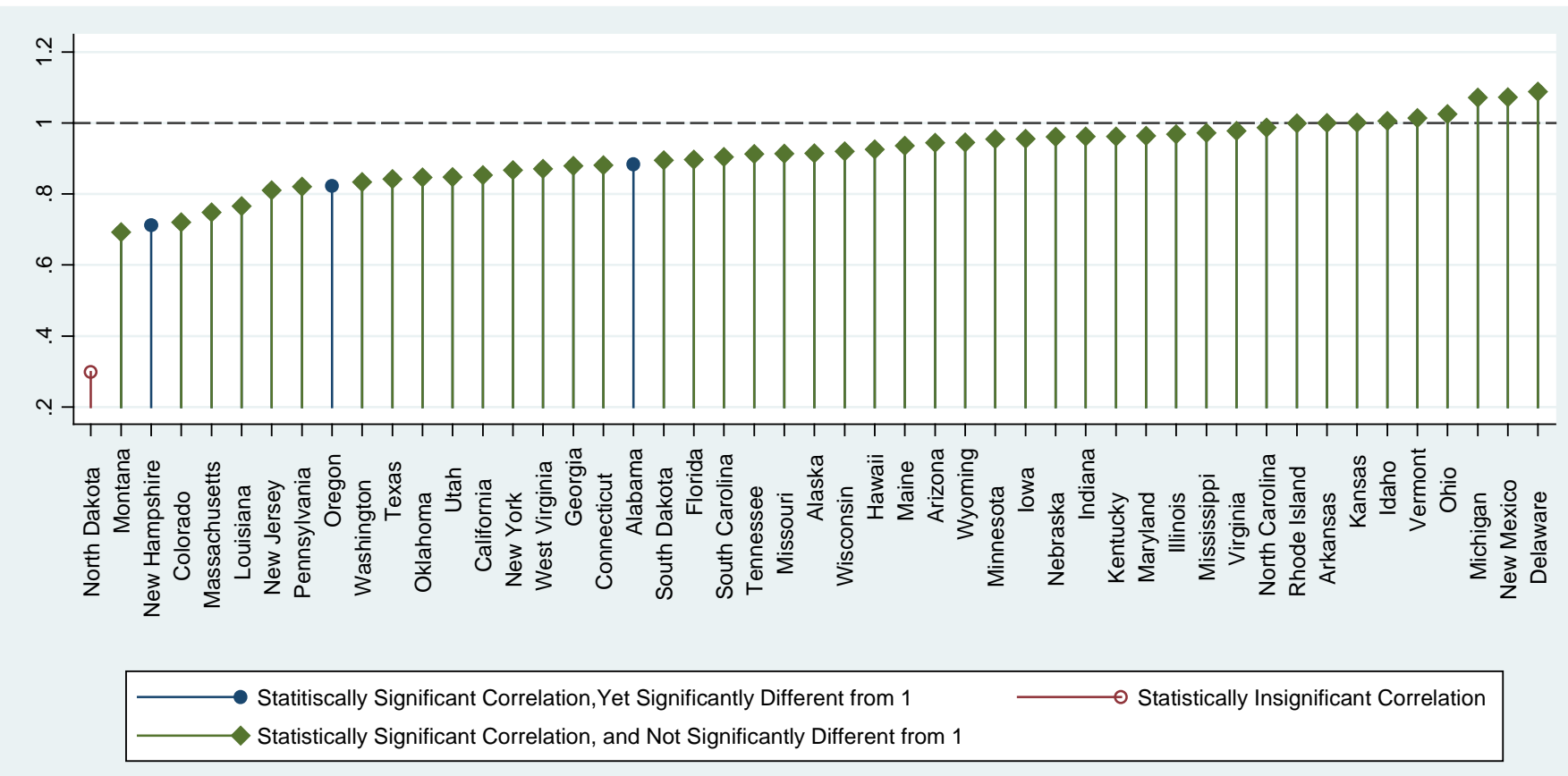

Table 3. Cointegration Tests Using Westerlund Error-Correction-Based Panel CointegrationTests a. Cointegration between welfare expenditure and state government ideology

\begin{tabular}{|c|c|c|c|}
\hline Statistics & Value & Z-value & P-value \\
\hline Gt & -5.098 & -23.529 & 0.000 \\
\hline
\end{tabular}

b. Cointegration between welfare expenditure and trade exposure $\times$ state government ideology

\begin{tabular}{|c|c|c|c|}
\hline Statistics & Value & Z-value & P-value \\
\hline Gt & -5.876 & -30.235 & 0.000 \\
\hline
\end{tabular}

We have also used the Westerlund error-correction-based panel cointegration tests (Stata Command xtwest) to explore the cointegration structure of our data (Westerlund, 2007; Persyn \& Westerlund, 2008). Table 3(a) and 3(b) show the results. For the Gt test statistics, rejection of $\mathrm{H}_{0}$ should be taken as evidence of cointegration in at least one of the cross-sectional units. Our cointegration tests show that our dependent variable (welfare expenditure) and state government ideology are cointegrated in at least one state; welfare expenditure and the interaction term 
between trade exposure and state government ideology are also cointegrated in at least one state. Our second and third dependent variables (i.e., infrastructure expenditure and education expenditure) are cointegrated with all three core independent variables in at least one state. Earlier

scholars such as Banerjee, Dolado, Galbraith and Hendry (1993) introduce ECM as an appropriate estimation technique for non-stationary and cointegrated time series data. More recently scholars such as DeBoef and Keele argue that ECM could be used in a much wider range of scenarios. Considering that our dependent variables are non-stationary and cointegration is also detected in our panel data, we adopt the ECM. In an ECM, the first-difference of the dependent variable is estimated as an equation of the lagged dependent variable, the first difference and the lagged independent variables. An advantage of the ECM is that this model estimates both the long-term and the short-term effects of the independent variables on the dependent variables. Therefore, we specify our CSTS model as:

$\Delta \mathrm{Y}_{\mathrm{i}, \mathrm{t}}=\mathrm{a}+\mathrm{b}_{1} \times \mathrm{Y}_{\mathrm{i}, \mathrm{t}-1}+\mathrm{b}_{2} \times \Delta \mathrm{X}_{\mathrm{i}, \mathrm{t}}+\mathrm{b} 3 \times \mathrm{X}_{\mathrm{i}, \mathrm{t}-1}+\mathrm{e}_{\mathrm{i}, \mathrm{t}}$

\section{Characteristics of the error term}

Lastly, we consider the characteristics of the error term after estimating the model. We test for heteroskedasticity, groupwise heterogeneity, and contemporaneous correlation of our error term. The Breusch-Pagan/Cook-Weisberg test for heteroskedasticity reports a chi-square of 116.34 and a p-value of 0.0000, suggesting that there is heteroskedasticity in our error term (Breusch, Ward, Nguyen \& Kompas, 2011). A modified Wald statistic for groupwise heteroskedasticity (xttest3) reports a chi-square of 3187.17 and p-value of 0.0000, suggesting that cross-sectional heteroskedasticity also exists (Greene, 2011). Lastly, the Frees' test of contemporaneous correlation reports a test score of 7.208, which is larger than the critical values from Frees' Q distribution and therefore suggests that contemporaneous correlation is detected (Frees, 1995). To 
sum up, heteroskedasticity, groupwise heteroskedasticity and contemporaneous correlation are all detected in our CSTS data. Beck and Katz $(1995,1996)$ suggest using the panel-corrected standard errors (PCSEs) if both panel heteroskedasticity and contemporaneous correlation are detected. Therefore, we use the PCSEs together with our error correction models.

The Durbin-Watson d-Test for serial correlation suggests that there is positive serial correlation (rho=0.97). Keele and Kelly (2006) suggest that including a lagged dependent variable can often resolve serial correlation. Since our error correction model is equivalent to an autoregressive distributed lag (ADL) model according to DeBoef and Keele (2008) and has already included a lagged dependent variable, the serial correlation issue should be addressed by the ECM itself. Another Durbin-Watson d-Test finds that the serial correlation does disappear when we include a lagged dependent variable in our model.

To conclude, our dependent variable welfare expenditure as a \% of GSP is non-stationary and cointegrated with our core independent variables; therefore the error correction model (ECM) is the most appropriate model specification. Additionally, given that panel heteroskedasticity and contemperaneous correlation are both detected in the error terms, we use panel-corrected standard errors (PCSEs) with the ECM.

\section{Comparing the Full ECM with More Restricted Models}

In order to make sure that a full dynamic model is necessary, we compare a full ECM with the following three restricted models: (1) Partial Adjustment model, (2) Differences model, and (3) Dead Start model. The specifications of all the models are as below:

General ECM model: $\Delta \mathrm{Y}_{\mathrm{i}, \mathrm{t}}=\mathrm{a}+\mathrm{b}_{1} \times \mathrm{Y}_{\mathrm{i}, \mathrm{t}-1}+\mathrm{b}_{2} \times \Delta \mathrm{X}_{\mathrm{i}, \mathrm{t}}+\mathrm{b}_{3} \times \mathrm{X}_{\mathrm{i}, \mathrm{t}-1}+\mathrm{e}_{\mathrm{i}, \mathrm{t}}$ Partial Adjustment model: $\Delta \mathrm{Y}_{\mathrm{i}, \mathrm{t}}=\mathrm{a}+\mathrm{b}_{1} \times \mathrm{Y}_{\mathrm{i}, \mathrm{t}-1}+\mathrm{b}_{2} \times \mathrm{X}_{\mathrm{i}, \mathrm{t}}+\mathrm{e}_{\mathrm{i}, \mathrm{t}}$ Differences model: $\Delta \mathrm{Y}_{\mathrm{i}, \mathrm{t}}=\mathrm{a}+\mathrm{b}_{1} \times \Delta \mathrm{X}_{\mathrm{i}, \mathrm{t}}+\mathrm{e}_{\mathrm{i}, \mathrm{t}}$ 
Dead Start model: $\Delta \mathrm{Y}_{\mathrm{i}, \mathrm{t}}=\mathrm{a}+\mathrm{b}_{1} \times \mathrm{Y}_{\mathrm{i}, \mathrm{t}-1}+\mathrm{b}_{2} \times \mathrm{X}_{\mathrm{i}, \mathrm{t}-1}+\mathrm{e}_{\mathrm{i}, \mathrm{t}}$

By using a joint F test between the general ECM and each of the restricted model we have obtained the following F statistics:

(1) Partial Adjustment model and the general ECM: $F=9.32(p=0.0000)$

(2) Differences model and the general ECM : F=6.25 ( $p=0.0000)$

(3) Dead Start model and the general ECM: $F=17.44(p=0.0000)$

The F test results suggest that the coefficients for the additional variables in the full ECM that the restricted models do not contain are significantly different from zero, or in other words these restricted models are not nested in a full ECM. In conclusion, a full ECM is more appropriate for our data than any of the three restricted models. Therefore, we are confident that a general ECM is appropriate. 
Work cited:

Allison, P. (2009). Fixed-effects regression models Quantitative applications in the social sciences. Thousand Oaks, CA: Sage Publications.

Banerjee, A., Dolado, J., Galbraith, J. W., \& Hendry, D. F. (1993). Co-integration, errorcorrection, and the econometric analysis of non-stationary data. New York: Oxford University Press.

Beck, N., \& Katz, J. N. (1995). What to do (and not to do) with time-series cross-section data. American Political Science Review, 89, 634-647.

Beck, N., \& Katz, J. N. (1996). Nuisance versus substance: Specifying and estimating time-series corss-section models. Political Analysis, 6, 1-36.

Breusch, T., Ward, M. B., Nguyen, H. T. M., \& Kompas, T. (2011). Just iv or just mistaken? Political Analysis, 19, 165-169.

De Boef, S., \& Keele, L. (2008). Taking time seriously. American Journal of Political Science 52, 184-200.

Dickey, D. A., \& Fuller, W. A. (1979). Distribution of the estimators for autoregressive time series with a unit root. Journal of the American Statistical Association, 74, 427-431.

Frees, E. W. (1995). Assessing cross-sectional correlations in panel data. Journal of Econometrics, 69, 393-414.

Greene, W. (2011). Econometric analysis (7th Edition ed.). New York: Prentice Hall.

Hausman, J. A. (1978). Specification tests in econometrics. Econometrica, 46, 1251-1271.

Persyn, D., \& Westerlund, J. (2008). Error correction based cointegration tests for panel data. Stata Journal, 8, 232-241. 
Phillips, P. C. B., \& Perron, P. (1988). Testing for a unit root in time series regression. Biometrika, 75, 335-346.

Shor, B., \& McCarty, N. (2011). The ideological mapping of american legislatures. American Political Science Review, 105, 530-551.

Westerlund, J. (2007). Testing for error correction in panel data. Oxford Bulletin of Economics and Statistics, 69, 709-748.

Zhu, L. (2013). Panel data analysis in public administration: Substantive and statistical considerations. Journal of Public Administration Research and Theory, 23, 395-428. 